\title{
Potassium Channels in Epilepsy
}

\author{
Rüdiger Köhling and Jakob Wolfart \\ Oscar Langendorff Institute of Physiology, University of Rostock, Rostock 18057, Germany \\ Correspondence: ruediger.koehling@uni-rostock.de
}

This review attempts to give a concise and up-to-date overview on the role of potassium channels in epilepsies. Their role can be defined from a genetic perspective, focusing on variants and de novo mutations identified in genetic studies or animal models with targeted, specific mutations in genes coding for a member of the large potassium channel family. In these genetic studies, a demonstrated functional link to hyperexcitability often remains elusive. However, their role can also be defined from a functional perspective, based on dynamic, aggravating, or adaptive transcriptional and posttranslational alterations. In these cases, it often remains elusive whether the alteration is causal or merely incidental. With $\sim 80$ potassium channel types, of which $\sim 10 \%$ are known to be associated with epilepsies (in humans) or a seizure phenotype (in animals), if genetically mutated, a comprehensive review is a challenging endeavor. This goal may seem all the more ambitious once the data on posttranslational alterations, found both in human tissue from epilepsy patients and in chronic or acute animal models, are included. We therefore summarize the literature, and expand only on key findings, particularly regarding functional alterations found in patient brain tissue and chronic animal models.

\section{INTRODUCTION TO POTASSIUM CHANNELS}

Dotassium $(\mathrm{K})$ channels are related to epilepsy syndromes on many different levels, ranging from direct control of neuronal excitability and homeostasis of ion milieu to indirect effects via metabolism. We discuss $\mathrm{K}$ channels and their relevance to epilepsy (1), in particular, with respect to genetic alterations in humans (2) and animal models (3), as well as acquired in humans (4) and animal models (5), and we highlight recent mechanisms on $\mathrm{K}$ channels in antiepileptic drug (AED) research (6).

Probably, all biological cells have K channels; they are crucial for all transmembrane transport mechanisms. In addition, since the evolutionary appearance of voltage-gated so$\operatorname{dium}\left(\mathrm{Na}_{\mathrm{v}}\right)$ and calcium $\left(\mathrm{Ca}_{\mathrm{v}}\right)$ channels, K channels are further diversified in relation to their newer function, namely, keeping neuronal excitation within limits (Anderson and Greenberg 2001; Hille 2001). Structurally, K channels consist of transmembrane (TM) protein elements similar to the $\mathrm{Ca}_{\mathrm{v}}$ and $\mathrm{Na}_{\mathrm{v}}$ channels and the cyclic nucleotide-regulated channels, with which the K channels can be grouped into a superfamily of "voltage-gated-like" ion channels (Yu et al. 2005; Alexander et al. 2013). The K-channel family is by far the largest: $<70$ human genes encoding for different $\alpha$ subunits have been discovered since the beginning of K-channel cloning (Fig. 1) (Coetzee et al. 1999; Goldstein et al. 2005; Gutman et al. 2005; Kubo et al. 2005; Wei

Editors: Gregory L. Holmes and Jeffrey L. Noebels

Additional Perspectives on Epilepsy: The Biology of a Spectrum Disorder available at www.perspectivesinmedicine.org

Copyright (C) 2016 Cold Spring Harbor Laboratory Press; all rights reserved; doi: 10.1101/cshperspect.a022871

Cite this article as Cold Spring Harb Perspect Med 2016;6:a022871 
et al. 2005; Trimmer 2015). With the formation of heteromers, modulating $\beta$ subunits, and differential expression, thousands of different $\mathrm{K}$ channels are possible. Four $\alpha$ subunits are necessary to build a functional K channel (Fig. 1). The $\alpha$ subunits are differentiated according to whether they consist of 2, 4, or 6TM domains. More common are functionally defined names such as "inward rectifier" $\mathrm{K}\left(\mathrm{K}_{\mathrm{ir}}\right)$ channels for 2TM channels, "leak two pore domain" K $\left(\mathrm{K}_{2 \mathrm{P}}\right)$ channels for $4 \mathrm{TM}$, and "voltage-gated" $\mathrm{K}\left(\mathrm{K}_{\mathrm{v}}\right)$ channels for 6TM (Fig. 1).

\section{Inward Rectifier Potassium Channels}

As the name suggests, $\mathrm{K}_{\mathrm{ir}}$ channels conduct inward current better than outward current; responsible for this is a magnesium or polyamine block at depolarized potentials (Kubo et al. 2005). However, under physiological conditions, the resting membrane potential $\left(\mathrm{V}_{\text {rest }}\right)$ of neurons is unlikely to become more negative than the equilibrium potential of $K$ ions $\left(E_{K}\right)$; the functional importance of $\mathrm{K}_{\mathrm{ir}}$ channels, such as the "classic leak $\mathrm{K}_{\mathrm{ir}}$ " channels of the $\mathrm{K}_{\mathrm{ir}} 2$ group, is to provide the basic $\mathrm{K}$ current maintaining $\mathrm{V}_{\text {rest }}$ (Stanfield et al. 2002). Some of the $K_{i r}$ channels are coupled to and modulated by G-proteins, among them, $\mathrm{K}_{\mathrm{ir}} 3$ (Girk) channels. In glial cells, $\mathrm{V}_{\text {rest }}$ can become more negative than $\mathrm{E}_{\mathrm{K}}$ during and because of spatial buffering of extracellular potassium concentrations $\left([\mathrm{K}]_{\mathrm{o}}\right)$, in particular via $\mathrm{K}_{\mathrm{ir}} 4$ channels (Butt and Kalsi 2006). Thus, Kir4.1 channels are found exclusively in glial cells (Higashi et al. 2001). The $\mathrm{K}_{\mathrm{ir}} 6\left(\mathrm{~K}_{\mathrm{ATP}}\right)$ channels are coupled to the intracellular energy supply; when ATP levels are high, $\mathrm{K}_{\mathrm{ir}} 6$ channels are closed, whereas during prolonged action potential (AP) firing $\mathrm{K}_{\mathrm{ir}} 6$ channels will eventually contribute to resetting $\mathrm{V}_{\text {rest }}$ (Isomoto et al. 1997).

\section{Two Pore Domain Potassium Channels}

Also $\mathrm{K}_{2 \mathrm{P}}$ channels contribute to leak current important for $\mathrm{V}_{\text {rest }}$ (Lesage and Lazdunski 2000; Goldstein et al. 2001). Hence, functionally, some of these, for example, the "tandem of $\mathrm{P}$ domains in weak inward rectifier (TWIK)” K channels, behave similarly to $\mathrm{K}_{\mathrm{ir}}$ channels with high $[\mathrm{K}]_{\mathrm{o}}$. Under physiological conditions, most of the $\mathrm{K}_{2 \mathrm{P}}$ channels are open rectifiersthey conduct mainly outward K currents (Goldstein et al. 2001). In addition, $K_{2 P}$ channels integrate other signals, as in the case of TWIKrelated acid-sensitive (TASK) channels, which are sensitive to external $\mathrm{pH}$ changes (Lesage and Lazdunski 2000; Goldstein et al. 2001). From the human genetics point of view, there is little association between $\mathrm{K}_{2 \mathrm{P}}$ channels and epilepsy, but there are data on $\mathrm{K}_{2 \mathrm{P}}$ channels in seizure models (see below). Note that there is no simple correlation between the functional (historical) naming and the later classification according to a sequence relationship (TWIK1, $\mathrm{K}_{2 \mathrm{P}} 1.1$; TWIK2, $\mathrm{K}_{2 \mathrm{P}} 6.1$; TASK1, $\mathrm{K}_{2 \mathrm{P}} 3.1$; TASK2, $\mathrm{K}_{2 \mathrm{P}} 5.1$ ).

\section{Voltage-Gated Potassium Channels}

The largest ion channel group is the $\mathrm{K}_{\mathrm{v}}$ channel family, which consists of $12 \mathrm{~K}_{\mathrm{v}}$ (sub-) families. The founding group, the shaker-related $\mathrm{K}_{\mathrm{v}} 1$ channel family was named after the muscle seizure phenotype of the corresponding fly mutant (Pongs et al. 1988). Subsequently discovered groups were classified as shab-related $\left(\mathrm{K}_{\mathrm{v}} 2\right)$, shaw-related $\left(\mathrm{K}_{\mathrm{v}} 3\right)$, and shal-related $\left(\mathrm{K}_{\mathrm{v}} 4\right)$ (Coetzee et al. 1999; Gutman et al. 2005). From the functional point of view, all $\mathrm{K}_{\mathrm{v}}$ channels are activated by depolarization and deactivated by repolarization, both relatively fast. Inactivation occurs when the open channel is occluded via intracellular "ball domains" during prolonged depolarization. When inactivation is fast (i.e., visible within tens of milliseconds), it is called "A-type current" after the initial description in the gastropod Anisodoris (Connor and Stevens 1971). Such ball domains can be part of the channel like in the case of the Atype subunits $\mathrm{K}_{\mathrm{v}} 1.4, \mathrm{~K}_{\mathrm{v}} 3.4$, and $\mathrm{K}_{\mathrm{v}} 4$, or they are part of an accessory unit, as in the case of the $\mathrm{K}_{\mathrm{v}} \beta 1.1$ (KCNMB1), which confers the A-type phenotype on the $\mathrm{K}_{\mathrm{v}} 1$ subunits it assembles with (Rettig et al. 1992, 1994). The term "delayed rectifier" outward current $\left(\mathrm{I}_{\mathrm{K}}\right)$ describes the delayed activation relative to the ultrafast ( $\mu \mathrm{sec}$ range) activation of $\mathrm{Na}_{\mathrm{v}}$ currents (Hodgkin and 

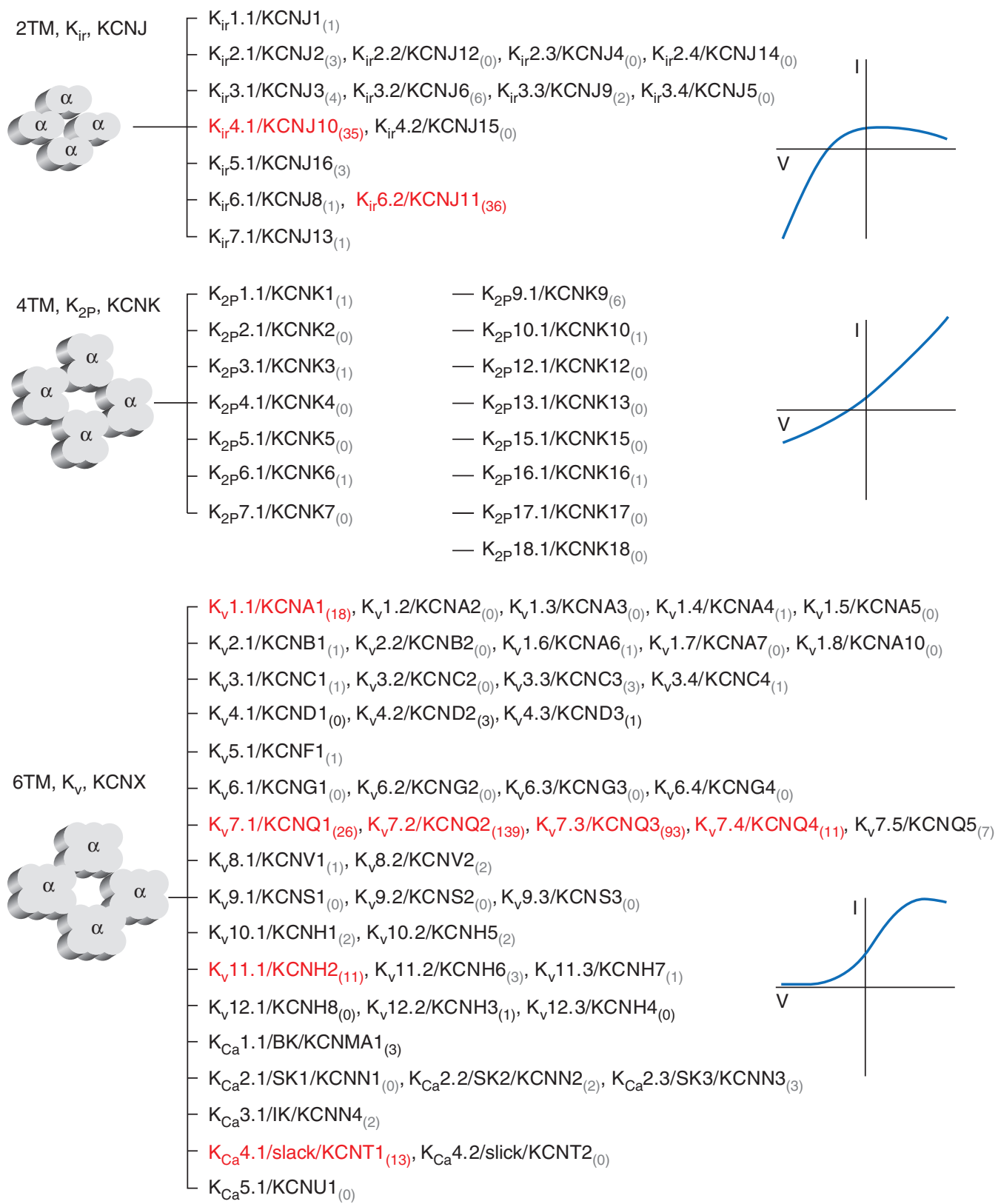

Figure 1. Tree of mammalian potassium channel subunits and epilepsy research hot spots. The figure shows the known potassium $(\mathrm{K})$ channel $\alpha$ subunits families and epilepsy research hot spots. Their relation is grouped according to sequence similarities in three major groups: two, four, and six transmembrane (TM) domain channels (2TM, 4TM, and 6TM, respectively), which are synonymously named according to gross functional differences as: inward rectifier $\mathrm{K}\left(\mathrm{K}_{\mathrm{ir}}\right)$, two-pore domain leak $\mathrm{K}\left(\mathrm{K}_{2 \mathrm{P}}\right)$, and voltage-gated $\mathrm{K}\left(\mathrm{K}_{\mathrm{v}}\right)$ channels, respectively. Hypothetical (not realistic for individual members) main characteristics of the respective current/voltage relationships are plotted in insets as blue lines. Following the functional name, is the human genome organization (HUGO) name. Numbers in parenthesis are PubMed search results for "(HUGO AND epilepsy) AND Humans[Filter] NOT Review[Filter]." Marked in red are those subunits that yielded more than 10 results in this PubMed search. 
Huxley 1952). $\mathrm{K}_{\mathrm{v}} 4$ channels typically have a tendency to reside in dendrites (Rhodes et al.2004), whereas most $\mathrm{K}_{\mathrm{v}} 1$ proteins are axonal (Monaghan et al. 2001), similar to $\mathrm{K}_{\mathrm{v}} 3.4$ (Riazanski et al. 2001). There are also slower forms of inactivation like the "delay" current, which inactivates within hundreds of milliseconds up to seconds; this current is mediated by $\mathrm{K}_{\mathrm{v}} 1.1, \mathrm{~K}_{\mathrm{v}} 1.2$, and/or $\mathrm{K}_{\mathrm{v}} 1.6$ subunits (Storm 1988; Kirchheim et al. 2013). Although many groups have defined A-type currents as those blocked by millimolar concentrations of 4-amminopyridine (4-AP), it should be noted that all $\mathrm{K}_{\mathrm{v}} 1$ channels containing the subunits, which mediate the delay current, are also sensitive to 4-AP, even in the micromolar range (as well as to $\mathrm{nm}$ dendrotoxin, DTX) (Storm 1988; Stuhmer et al. 1989; Grupe et al. 1990; Grissmer et al. 1994). Thus, within $K_{v}$ families, $\alpha$ subunits form heteromultimeric tetramers with mixed biophysical and pharmacological properties (Ruppersberg et al. 1990; Hatton et al. 2001), such that precise and unambiguous identification of native functional $\mathrm{K}_{\mathrm{v}}$ channels remains difficult. The location and properties of $\mathrm{K}_{\mathrm{v}} 1$ channels suggests that their function in the central nervous system (CNS) is mainly to shape the duration and delay of axonal action potentials (Sheng et al. 1994; Wang et al. 1994; Rhodes et al. 1997; Monaghan et al. 2001; Wenzel et al. 2007; Kirchheim et al. 2013).

A particular epilepsy hot spot is in the $\mathrm{K}_{\mathrm{v}} 7$ family of which the founding members dominate the repolarization of the heart $\mathrm{AP}$ and thereby the interval between the Q peak and T wave of the electrocardiogram (EKG). Therefore, mutations in the cardiac $\mathrm{K}_{\mathrm{v}} 7.1$ (KCNQ1/ $\mathrm{K}_{\mathrm{v}} \mathrm{LQT} 1$ ) channel lead to the long QT (LQT) syndrome (Barhanin et al. 1996; Wang et al. 1996) and its expression in brain has been linked to epilepsy and sudden unexpected death (Goldman et al. 2009). The $\mathrm{K}_{\mathrm{v}} 7.2$ and $\mathrm{K}_{\mathrm{v}} 7.3$ subunits are widely expressed in the brain where they mediate the neuronal $\mathrm{M}$-current $\left(\mathrm{I}_{\mathrm{M}}\right)$, which is muscarine-modulated and contributes to sub-AP-threshold excitability, whereas the $\mathrm{K}_{\mathrm{v}} 7.4$ channel has an important function in the inner ear (Jentsch 2000). The $\mathrm{K}_{\mathrm{v}} 11.1$ or "human ether à go-go-related gene type 1" (HERG1) K channels conduct a very slowly ac- tivating $I_{K}$ in the heart (Gutman et al. 2005). This channel is mutated in the LQT2 syndrome. However, as HERG1 is also widely expressed in the brain, its mutation could also be involved in certain forms of epilepsies (Sanguinetti 2010).

\section{Calcium-Dependent Potassium Channels}

From the structural perspective, the calciumdependent $\mathrm{K}\left(\mathrm{K}_{\mathrm{Ca}}\right)$ channels belong to the $\mathrm{K}_{\mathrm{v}}$ channels (Fig. 1), although functionally only some are dependent on voltage in addition to calcium (Wei et al. 2005). In a strict sense, calcium-dependent $\mathrm{K}$ channels are those named after their small, intermediate, and big conductance, that is, the SK1-3 $\left(\mathrm{K}_{\mathrm{Ca}} 2.1, \mathrm{~K}_{\mathrm{Ca}} 2.2\right.$, $\left.\mathrm{K}_{\mathrm{Ca}} 2.3\right)$, IK $\left(\mathrm{K}_{\mathrm{Ca}} 3.1\right)$, and $\mathrm{BK}\left(\mathrm{K}_{\mathrm{Ca}} 1.1\right)$ channels, respectively (Sah and Faber 2002). Because the $\mathrm{K}_{\mathrm{Ca}}$ nomenclature appears not well accepted, we continue to use the common SK and BK naming. These channels mediate different parts of the AP after-hyperpolarization (AHP), in particular the fast ( $<\mathrm{msec}$ ) AHP (fAHP, BK), and the medium duration $(\sim 100 \mathrm{msec})$ AHP (mAHP, SK). The channels mediating the slow AHP (sAHP) lasting seconds are heterogeneous. As with the $K_{v}$ channels, accessory $\beta$ subunits can strongly influence $\mathrm{K}_{\mathrm{Ca}}$ channel function. One example is the BK channel $\beta 4$ (KCNMB4) subunit, which functionally reduces BK currents (Brenner et al. 2000; Lippiat et al. 2003). Further complicating the nomenclature, the channels classified $\mathrm{K}_{\mathrm{Ca}} 4$, are actually sodium dependent (not calcium dependent); one example is the "sequence like a slowpoke calcium-activated" (SLACK, Slo2.2, or $\mathrm{K}_{\mathrm{Ca}} 4.1$ ) channel (Bhattacharjee and Kaczmarek 2005).

\section{GENETIC ALTERATIONS ASSOCIATED WITH EPILEPSIES: PATIENT DATA}

Here, we briefly summarize the known genetic mutations associated with epilepsies in humans ( for more detailed accounts, see Jentsch 2000; Kullmann 2002; Mulley et al. 2003; George 2004; Steinlein 2004; Brenner and Wilcox 2012; D’Adamo et al. 2013; Lerche et al. 2013). We will follow the broad K-channel classification defined above. 


\section{Voltage-Gated Potassium Channels}

In 1998, four different groups reported that mutations in $\mathrm{K}_{\mathrm{v}} 7.2$ or $\mathrm{K}_{\mathrm{v}} 7.3$ channels are associated with a specific neonatal type of epilepsy, benign familial nocturnal convulsions (BNFCs), inherited in an autosomal dominant fashion (Biervert et al. 1998; Charlier et al. 1998; Schroeder et al. 1998; Singh et al. 1998). By the year 2000, $>10$ mutations of the proteins (mainly $\mathrm{K}_{\mathrm{v}} 7.2$, two in $\mathrm{K}_{\mathrm{v}} 7.3$ ) were identified, all leading to a reduction of $\mathrm{I}_{\mathrm{M}}$ and increased AP rates (Jentsch 2000). Another 12 years later, the numbers increased to $>60$ known mutations in $\mathrm{K}_{\mathrm{v}} 7.2$ and four in $\mathrm{K}_{\mathrm{v}} 7.3$ (Brenner and Wilcox 2012), and they continue to increase (Soldovieri et al. 2014; Miceli et al. 2015), again mainly causing infantile epilepsies (i.e., BNFC and rolandic epilepsies) (Neubauer et al. 2008). Although a reduction in $\mathrm{I}_{\mathrm{M}}$ provided a mechanistic link to hyperexcitability (Fig. 2), the transient phenotype of BNFC, at least in most patients, still cannot be explained on the grounds of these mutations, or why in some cases they are associated with not-so-benign epilepsies. Thus, some of these mutations (among them de novo) are linked to quite different and more severe epilepsy syndromes, such as Ohtahara syndrome (drug-resistant seizures, psychomotor retardation, burst-suppression EEG) (Weckhuysen et al. 2012, 2013; Soldovieri et al. 2014). This "case history" of one key K-channel type whose genetic mutations are connected to epilepsies exemplifies the general dilemma of genetic/phenotypic correlations. Mutations may generate small or even seemingly paradoxical functional changes, they may result in very different syndromes, or they may lack penetrance, with carriers of these mutations being totally asymptomatic. Conversely, patients with similar, clinically well-defined syndromes may not display any mutation in the relevant $\mathrm{K}$ channel. Despite these dilemmata, such genetic findings help to explain the neurobiological basis of epilepsies and, in some cases, directly lead to therapeutic translation.

A recent article by Syrbe et al. (2015) serves as a good example of the mentioned dilemma. Six mutations in the $\mathrm{K}_{\mathrm{v}} 1.2$ channel genes were associated with different types of juvenile epilepsies and mild to moderate intellectual disability ( focal, focal dyscognitive, myoclonic, absences, and mainly secondary generalized tonic clonic). The $\mathrm{K}_{\mathrm{v}} 1.2$ mutations associated with epileptic encephalopathies described in this study were found to result in both a gain or, alternatively, a loss of current function. Even if at present the findings fail to unveil a functionally unifying concept (i.e., cannot explain why a gain or a loss of function both result in the same syndrome; Fig. 2), the fact that 4-AP as an approved drug for human use can reduce these currents is currently triggering clinical studies for patients with the gain-of-function mutation. In addition, a mutation in a gene favoring inactivation of $\mathrm{K}_{\mathrm{v}} 1$ channels, leucine-rich glioma inactivated 1 gene (LGI1), which in its mutated form does not prevent inactivation, is associated with a rare epilepsy, autosomal dominant partial epilepsy with auditory features, a form of idiopathic lateral temporal lobe epilepsy characterized by partial seizures with auditory disturbances (Kalachikov et al. 2002).

Mutations in $\mathrm{K}_{\mathrm{v}} 1.1$ subunits were first described to be associated mainly with episodic ataxia type 1, that is, a cerebellar phenotype, and only sometimes (in two different mutations) additionally with partial epilepsy with secondary generalization (Zuberi et al. 1999) or generalized seizures (VanDyke et al. 1975). Functionally, the mutations described by the latter investigation result in a graded and expression-dose-dependent reduction of the $\mathrm{K}$ currents in oocyte expression systems, arguably supporting a reduction-of-repolarization hypothesis. Recently a de novo mutation in the $\mathrm{K}_{\mathrm{v}} 3.1$ channel was described, which is associated with another rare epilepsy type, progressive myoclonus epilepsy of the Unverricht-Lundborg type, consisting of action myoclonus, tonic-clonic seizures, and ataxia (Muona et al. 2015). This channel type has been described to mediate fast firing in cerebellar neurons (Pedroarena 2011), but is also widely expressed in hippocampal and neocortical interneurons (Ozaita et al. 2002; Gutman et al. 2005), suggesting that a loss of function should be associated with reduced inhibitory cell firing (Fig. 2). 


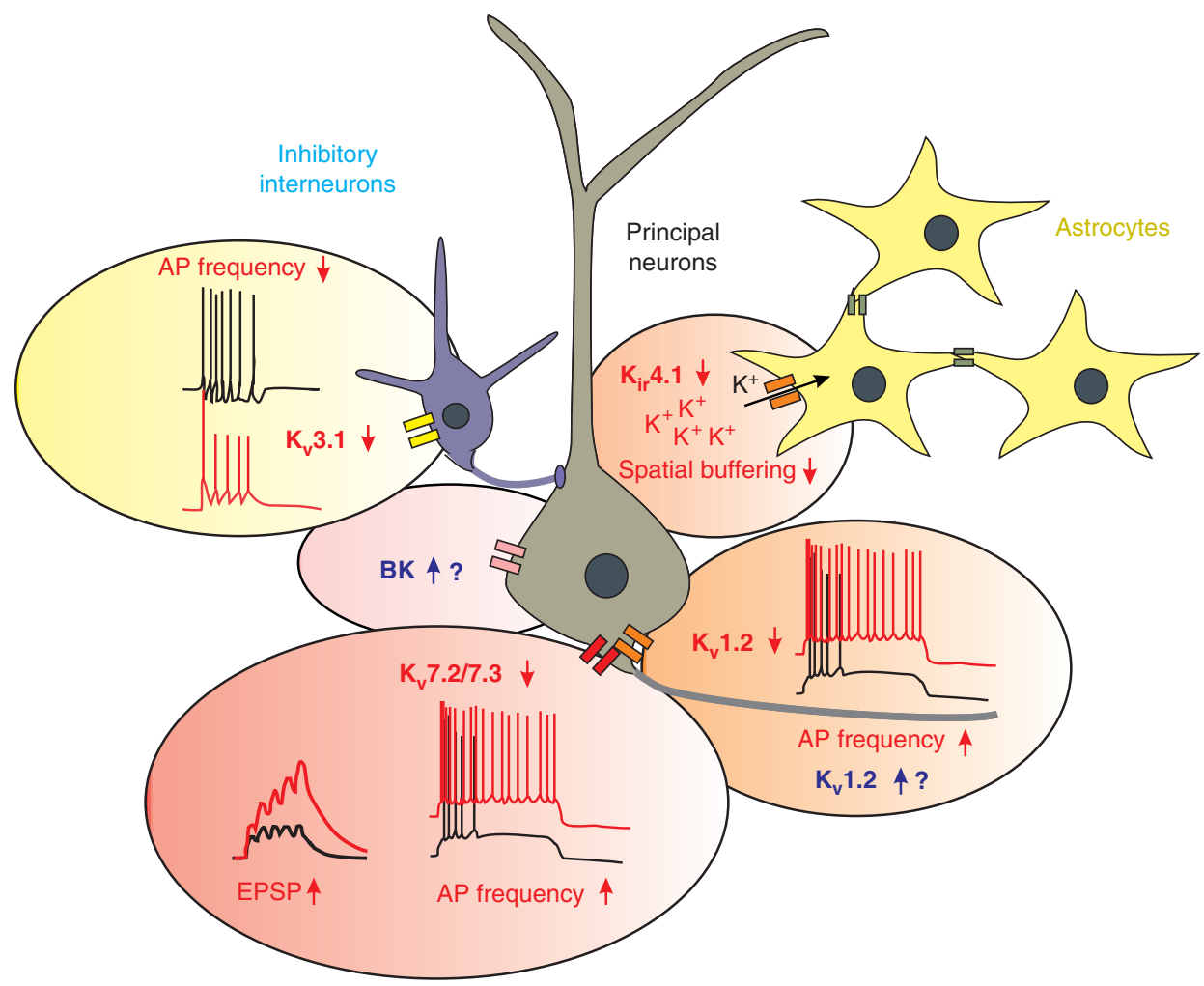

Figure 2. Possible mechanisms of the main genetic potassium channel defects found in epilepsy patients. The cartoon illustrates the localization and effect of loss-of-function $(\downarrow)$ or gain-of-function $(\uparrow)$ mutations of $\mathrm{K}_{\mathrm{v}} 7.2 / 7.3$ (KCNQ channels), $\mathrm{K}_{\mathrm{v}} 1.2$, BK $\left(\mathrm{K}_{\mathrm{Ca}} 1.1\right), \mathrm{K}_{\mathrm{v}} 3.1$, and $\mathrm{K}_{\mathrm{v}} 4.1$. Normal conditions are symbolized by black traces, functional changes caused by mutations in red. $\mathrm{K}_{\mathrm{v}} 7.2 / 7.3$ channels are mainly located on axons and axoninitial segments of neurons, and are usually active at resting membrane potential, thereby governing excitability at the axon hillock. A loss-of-function mutation should result in both accentuated excitatory postsynaptic potentials (EPSPs) as well as in increased action potential firing, which would readily explain hyperexcitability-however, does not explain the association with either relatively benign syndromes like benign familial nocturnal convulsion (BNFC), or relatively severe syndromes like Ohthara syndrome. In a similar way, a lossof-function mutation of $\mathrm{K}_{\mathrm{v}} 1.2$, also expressed on the axon hillock, but constituting a delayed rectifier channel not constitutively open at rest, will likely increase action potential firing frequency, again accounting for increased hyperexcitability. The gain-of-function mutations also described in patients, however, remain difficult to explain mechanistically (?). This also applies for $\mathrm{BK}\left(\mathrm{K}_{\mathrm{Ca}} 1.1\right)$ channel defects, in which gain-of-function alterations do not readily conjure a mechanism (?). Mutations of $\mathrm{K}_{\mathrm{v}} 3.1$, in turn, could elicit an overall increase in excitability, as these channels are expressed mainly on interneurons and convey, by virtue of their fast hyperpolarizing action, fast-firing properties to them. Should these fail, interneurons are expected to fire less intensively. Last, mutations of $\mathrm{K}_{\mathrm{ir}} 4.1$ have been described. As these are expressed on astrocytes and are responsible for uptake of potassium (spatial buffering), a loss of function should result in decreased spatial buffering and, hence, activity-dependent pathological accumulation of $\mathrm{K}^{+}$with an overall excitatory effect by depolarizing neighboring cells.

Although the $\mathrm{K}_{\mathrm{v}} 2$ channels have not yet been much implicated in epilepsies, two mutations in a $\mathrm{K}_{\mathrm{v}} 2.1$-channel modifier $\left(\mathrm{K}_{\mathrm{v}} 8.2\right)$ were found to be associated with a mild form of febrile seizures or a severe form of encephalopathy with seizures, respectively (Jorge et al. 2011). Consis- tently, the respective mutation reduced $\mathrm{K}_{\mathrm{v}} 2.1$ currents in a coexpression system. Last, another rare form of multisystem developmental disorder associated with epilepsy and intellectual disability, Temple-Baraitser syndrome, appears to be linked to a gain-of-function mutation in the 
gene for $\mathrm{K}_{\mathrm{v}} 10.1$ (eag1) channels (Simons et al. 2015). This mosaic mutation (in two mothers of affected children) apparently results in epilepsy. Thus, interfering with $\mathrm{I}_{\mathrm{K}}$ appears to increase the risk for mainly severe epilepsies, and perhaps encephalopathy. The examples given are rare-perhaps reflecting the possibility that other mutations simply are not viable and lead to death in utero, something that might be expected if a major repolarizing current is reduced or fails altogether. Another factor may be that fast firing in interneurons could be affected, for example, in the case of mutations of $\mathrm{K}_{\mathrm{v}} 3.1$ (Muona et al. 2015). Inactivating $K_{v}$ channels, which mediate A-type currents, shape presynaptic calcium transients and repetitive AP firing both orthodromically as well as backpropagating into the dendrites. An association of this functional group has been found in only one patient so far, and it involves a mutation of $\mathrm{K}_{\mathrm{v}} 4.2$, leading to current reduction (Singh et al. 2006). In cardiology, the $K_{v} 11.1$ channels are long known to cause severe repolarization problems (similar to $\mathrm{K}_{\mathrm{v}} 7$ mutations); these $\mathrm{K}_{\mathrm{v}} 11$ channels are also increasingly considered to contribute to combined reflex epilepsy and arrhythmia, as well as to increased risk for sudden unexpected death in epilepsy (SUDEP) (cf. Zamorano-Leon et al. 2012; D’Adamo et al. 2013).

\section{Calcium-Activated Potassium Currents}

The $\mathrm{K}_{\mathrm{Ca}}$ channels are interesting functionally, as their activation is linked to the amount of previous neuronal activity via the accumulated calcium influx at various time scales. Although BK channels, and in some cases the SK channels, activate the SK currents particularly increase with pathological hyperexcitation. In the context of human epilepsies, the BK channels have been at the focus of attention. Du et al. (2005) described a gain-of-function mutation in the $\alpha 1$ subunit of this channel with absence epilepsy presenting in $\sim 50 \%$ of the affected patients (with the other cardinal symptom being paroxysmal dyskinesia); this effect was ascribed to more effective $\mathrm{Ca}^{2+}$ coupling of this channel (Yang et al. 2010). In a set-association analysis trying to link single nucleotide polymorphisms
(SNPs) to epilepsies in different populations, a faint association between a mutation of the negative regulatory $\beta 4$ subunit of BK channels and temporal lobe epilepsy (TLE) was found in a population-specific manner (in the Irish subset of the sample only). It would probably be stretching the evidence to ascribe gain-of-function disturbances to cortico-thalamic-circuitryassociated epilepsies (such as absence epilepsy) and loss-of-function types (presumably this SNP, although not functionally evaluated) to TLE, but such speculations have been raised (N'Gouemo 2011). To complete this list, a sporadic case of autosomal dominant nocturnal frontal lobe epilepsy (ADNFLE) was reported to carry a mutation in the SLACK $\left(\mathrm{K}_{\mathrm{Ca}} 4.1\right)$ gene (Heron et al. 2012).

\section{Inward Rectifier Potassium Channels}

In epilepsy patients, mainly mutations of the astrocytic $\mathrm{K}_{\mathrm{ir}} 4.1$ channel have been reported (Ferraro et al. 2004; Olsen and Sontheimer 2008). The symptoms resulting from these mutations can range from increased seizure susceptibility (missense variation) (Buono et al. 2004), or TLE (significant single nucleotide polymorphism association in Norwegian patient sample) (Heuser et al. 2010, 2012) to a severe combined syndrome of epilepsy, ataxia, sensorineural deafness, and tubulopathy (EAST) syndrome with $\mathrm{K}_{\mathrm{ir}} 4.1$ loss of function (Bockenhauer et al. 2009; Scholl et al. 2009). A loss of function of 4.1 channels, located in astrocytes, could be associated with infringed astrocytic spatial buffering and consecutive activity-dependent pathological accumulation of $\mathrm{K}^{+}$and neuronal depolarization (Fig. 2). A speculative link to epilepsy arises also with $\mathrm{K}_{\mathrm{ir}} 2.1$ loss-of-function mutations. These are associated with Andersen-Tawil syndrome (periodic paralysis, cardiac arrhythmias, dysmorphic features, and slight cognitive limitations) in a fraction of these patients $(\sim 1 / 5)$, there is a history of febrile seizures as infants (Haruna et al. 2007). The investigators discussed this as a possible effect of impaired astrocytic spatial buffering; however, the latter is thought to be carried by $\mathrm{K}_{\mathrm{ir}} 4.1$ and not $\mathrm{K}_{\mathrm{ir}} 2.1$ (Jabs et al. 
2008), so the link to epilepsy remains elusive at the moment. The association of $\mathrm{K}_{\mathrm{ir}} 6.2$ channels and epilepsy in the literature is mainly caused by KCNJ11 mutation-related subtypes of diabetes with epilepsy as comorbidity (Slingerland and Hattersley 2005; Shah et al. 2014). For example, a mutation in $\mathrm{K}_{\mathrm{ir}} 6.2$ results in a syndrome (DEND) of developmental delay, infantile diabetes, and epilepsy (Hattersley and Ashcroft 2005). All in all, cases of $K_{\text {ir }}$ mutations in epilepsy are rare. They can influence neuronal excitability as an epiphenomenon of an underlying disease, or, if mainly cerebral symptoms are present, different alterations in one channel type are associated with very different syndromes, sometimes multisystemic. This suggests that, as in some $K_{v}$ channels, a severe functional infringement in such an important current is probably often lethal, which would explain why human mutations are found only rarely.

In summary, it is safe to say that mutations in $\mathrm{K}_{\mathrm{v}} 7.2$ and $\mathrm{K}_{\mathrm{v}} 7.3$ are solidly validated as being causal for some forms of epilepsy, although such causality is less clearly established for the other mutations described.

\section{GENETIC ALTERATIONS ASSOCIATED WITH EPILEPSIES: ANIMAL DATA}

In the following section, the link between $\mathrm{K}$ channels and epilepsies is addressed from the other direction-not by searching for possible mutations in individuals affected by epilepsies, but by inducing genetic variation, usually in mice, and testing whether this results in some kind of epilepsy. Whenever possible, we indicate matches to the mutations of patients.

\section{Congenital Epilepsy Models}

Before discussing genetically modified animals, some underlying genetic causes of congenital epilepsies in animals should be mentioned; in a way, the approach of the former section now mirrored in seizure-prone animal strains. The most prominent human mutation, that is, affecting the $\mathrm{K}_{\mathrm{v}} 7.2$ channel, can also be found in an animal model with increased seizure susceptibility, the szt1 mouse, albeit in combination with a heterozygous mutation of the nicotinic acetylcholine receptor (Yang et al. 2003; Otto et al. 2004). Seizure-sensitive gerbils at least share a down-regulation (not mutation) of $\mathrm{K}_{\mathrm{v}} 3.1$ (and additionally $\mathrm{K}_{\mathrm{v}} 3.2$ ) with some patients of Unverricht-Lundborg epilepsy (Lee et al. 2009). Another similarity is the seizure susceptibility of DBA/2 mice, or Noda epileptic rats, which share features with TLE or EAST syndrome patients in that the $\mathrm{K}_{\mathrm{ir}} 4.1$ channels are less active, reducing astrocytic buffering capacity (Inyushin et al. 2010; Harada et al. 2013). The $\mathrm{K}_{\mathrm{ir}} 3$ channel gene is also involved in a prominent congenital model, the weaver mouse; in these animals, a mutation of the resulting in ion selectivity loss and reduced currents has been described (Patil et al. 1995; Slesinger et al. 1996). Genetically epilepsy-prone rats (Verma-Ahuja et al. 1995), in turn, link reductions of AHP to conditions in patients in which calcium-activated channels are mutated (a cautionary note: in the animal model, the slow AHP is down-regulated; in the human condition, with absences, it is a gain-of-function mutation [Du et al. 2005]). Other congenital channel mutations of animals associated to seizure phenotypes include the down-regulation of $\mathrm{K}_{2 \mathrm{P}} 6.1$ (TASK) channels in seizure-sensitive gerbils (Kim et al. 2007). The same TASK channel is mutated in a widespread model of absence epilepsy, the "genetic absence epilepsy rats from Strasbourg” (GAERS) (Holter et al. 2005). A complete ablation of TREK channels in mice, however, does not lead to any symptoms, which speaks against a direct causal role in epileptogenesis (Mirkovic et al. 2012).

\section{Voltage-Gated Potassium Channels}

The main epilepsy-associated human mutation, revolving around $\mathrm{K}_{\mathrm{v}} 7.2$ and $\mathrm{K}_{\mathrm{v}} 7.3$ channels and $\mathrm{BNFC}$, is also effective in animal models. A moderate loss of these channels suffices to induce a seizure phenotype (Schroeder et al. 1998). Proving this concept, conditional deletion of $\mathrm{K}_{\mathrm{v}} 7.2$ using a dominant negative mutation (Peters et al. 2005), or even $\mathrm{K}_{\mathrm{v}} 7.1$ (Goldman et al. 2009), induces discrete seizures and behavioral abnormalities (increased fear), or, in 
the latter case, seizures and SUDEP. This latter condition can also be mimicked by hyperSUMOylation of $\mathrm{K}_{\mathrm{v}} 7$ channels (Qi et al. 2014) and partly prevented by retigabine (see below). The combined homozygous $\mathrm{K}_{\mathrm{v}} 7.2 / \mathrm{K}_{\mathrm{v}} 7.3 \mathrm{mu}$ tant mouse also displays recurrent seizures, this time with a milder phenotype and no histopathological sequelae (at least in the hippocampus) (Singh et al. 2008). Deleting $\mathrm{K}_{\mathrm{v}} 7.2$, while simultaneously increasing the persistent sodium current, in a compound mutant with deleted $\mathrm{Na}_{\mathrm{v}} 1.2$ channels generates double trouble, as expected: a severe epilepsy with animals dying within 60 days (Kearney et al. 2006). In summary, these animal data seem to reasonably match the clinical situation (although not exactly reflecting the BNFC phenotype), with perhaps another grain of salt added that conditional cortical $\mathrm{K}_{\mathrm{v}} 7.2$ knockout induces severe epilepsy and early death, but not $\mathrm{K}_{\mathrm{v}} 7.3$ (however, in humans, $\mathrm{K}_{\mathrm{v}} 7.3$ mutations are much rarer) (Soh et al. 2014).

Regarding some of the transgenic and knockout models in the $\mathrm{K}_{\mathrm{v}} 1$ family, there is an incomplete overlap between human and animal data. Human epilepsies are only rarely associated with mutations of $K_{v} 1.1$. In mouse genetic models, deletion of $\mathrm{K}_{\mathrm{v}} 1.1$ (Robbins and Tempel 2012) leads to spontaneous seizure of a limbic phenotype (Smart et al. 1998), which is accompanied by electrophysiological and histopathological features of hippocampal hyperexcitability and sclerosis, respectively (Wenzel et al. 2007; Leonard et al. 2013; Simeone et al. 2013), or, in another mutation with premature stop codon, megalencephaly in addition to a seizure phenotype (Donahue et al. 1996; Petersson et al. 2003). Using a less targeted mutagenesis approach ( $\mathrm{N}$-ethyl- $\mathrm{N}$-nitrosourea mutagenization in rats), resulting in a missense mutation in $\mathrm{K}_{\mathrm{v}} 1.1$, also leads to epilepsy, in this case, tonic-clonic generalized, but also muscle symptoms (myokymia, neuromytonia) (Ishida et al. 2012). Even interfering with $\mathrm{K}_{\mathrm{v}} 1$ trafficking by knocking out the $\beta 2$ subunit induces hyperexcitability, but only occasionally seizures (Perkowski and Murphy 2011). The $\mathrm{K}_{\mathrm{v}} 1.1$ deletion is also discussed as a possible candidate mechanism for SUDEP, because it predisposes to brain driven cardiac arrhythmia during seizures (Glasscock et al. 2010; Moore et al. 2014). Curiously, these symptoms can be reduced by additional deletion of the $\mathrm{Ca}_{\mathrm{v}} 2.1$ channel (Glasscock et al. 2007), which illustrates how a mutant gene that increases transmitter release $\left(\mathrm{K}_{\mathrm{v}} 1\right)$ can be modified by one that depresses release at synaptic terminals (the P/Q type calcium channel). This model raises the possibility that balancing excitation and inhibition on the cellular level could be an antiepileptic strategy. However, the sum effect of such channel alterations are difficult to test in vivo as overexpression of the same $\mathrm{K}_{\mathrm{v}} 1.1$ channel leads to seizures, probably caused by multiple compensatory changes in other $K_{v}$ channels resulting from the genetic intervention (Sutherland et al. 1999). The intervention seems to work; however, when introduced into a chronic model of epilepsy, a neocortical tetanus toxin model, lentiviral overexpression of $\mathrm{K}_{\mathrm{v}} 1.1$ abolished electrographic seizures (Wykes et al. 2012). Although $\mathrm{K}_{\mathrm{v}} 1.2$ subunits colocalize with $\mathrm{K}_{\mathrm{v}} 1.1, \mathrm{~K}_{\mathrm{v}} 1.2$ knockout leads to rather different symptoms with brain stem seizures and early death (Brew et al. 2007). Thus, functionally, these channels do not appear to fully compensate for each other.

Similar to the human conditions, mutating the $\mathrm{K}_{\mathrm{v}} 2.1$ channel modifier $\mathrm{K}_{\mathrm{v}} 8.2$ in mice also results in severe, and prematurely lethal, epilepsy, but paradoxically with increased currents rather than decreased currents as in the human mutation (Jorge et al. 2011). Hence, the link of this study to the human condition is unclear. The investigators argue that the current deactivation is larger than in wild type, but once the irritating detail is spotted, the finding remains counterintuitive and definitively different from the human situation. There is only one study addressing mutations in the human $\mathrm{K}_{\mathrm{v}} 3.1$ channel, resulting in very severe epilepsy (Muona et al. 2015). A knockout in a sibling channel, $\mathrm{K}_{\mathrm{v}} 3.2$, leads to seizures in only a minority of affected animals, but has the electrophysiological markers of cortical hyperexcitability (Lau et al. 2000). To complete the list, a knockout of $\mathrm{K}_{\mathrm{v}} 12.2$, a channel that in the context of human epilepsy has not yet been described, also leads to seizures and/or increased seizure susceptibility 
(Zhang et al. 2010). Knockout of $\mathrm{K}_{\mathrm{v}} 4.2$ itself does not lead to epilepsy (Hu et al. 2006), but increases susceptibility for experimental seizure induction (Barnwell et al. 2009). A similar result is obtained when KChip2, a modulating subunit of $\mathrm{K}_{\mathrm{v}} 4$ channels, is knocked out, which leads to reduced current density and slowed recovery from inactivation - thus, altogether a lower fast current availability (Wang et al. 2013).

\section{Calcium-Activated Potassium Channels}

The main focus in $\mathrm{K}_{\mathrm{Ca}}$-related animal models was on BK channels or more precisely its negative modulator, the $\beta 4$ subunit. In a regional (Irish) patient sample, the $\beta 4$ gene was associated with TLE in an association study (see above). Introducing this gain-of-function mutation via dysfunctional $\beta 4$ subunits leads to limbic seizures in mice (Brenner et al. 2005; Wang et al. 2009), establishing at least a loose match between human and animal data.

\section{Inward Rectifier Potassium Channels}

Inward rectifying currents in patients are affected mainly in EAST syndrome, and perhaps relevant in regional populations regarding TLE. Reports of mutations in these channel types evoking seizures are equally rare. Knockout of astrocytic $\mathrm{K}_{\mathrm{ir}} 4.1$ channels leads to a lower threshold for stress-induced seizures (Neusch et al. 2006; Djukic et al. 2007). This deletion is also able to evoke pathologically altered EEG in zebrafish (Zdebik et al. 2013). Targeted introduction of $\mathrm{K}_{\mathrm{ir}} 6.1$ into presynaptic terminals of the hippocampus increases seizure susceptibility, although no outright spontaneous seizures emerge (Soundarapandian et al. 2007). Expanding the deletion to a general knockout, spontaneous sharp waves occur in the EEG (Yamada et al. 2001). This channel is a vascular sibling of the $\beta$-cell ATP-sensitive $\mathrm{K}_{\mathrm{ir}} 6.2$, whose deletion causes diabetes, whereas $\mathrm{K}_{\mathrm{ir}} 6.1$ deletion does not. Thus, the $K_{\mathrm{ir}} 6$ family has been implicated in epilepsy but only in the context of infantile diabetes - of which the seizures may be an epiphenomenon. In the kainate model, the link to genuine hyperexcitability is novel. Last, knockout of the $\mathrm{K}_{\mathrm{ir}} 3$ channel results in convulsions on handling or stress - a mutation that has not been found in patients so far (Signorini et al. 1997).

\section{ACQUIRED CHANGES ASSOCIATED WITH EPILEPSIES: DATA FROM HUMAN TISSUE}

\section{Acquired Channelopathy-Definition of Terms}

Unlike in animal models, with patients it is usually not known whether the channel abnormalities observed in resected tissue are already present since birth or whether they were acquired during epilepsy. Acquired channel modifications could be viewed as mechanisms confirming the old hypotheses of "seizures beget seizures" (Gower 1881) and "acquired epilepsy" (Smith et al. 1954). The term "channelopathy" (Wang et al. 1993) can be used for any diseasecausing channel alteration, whereas "acquired channelopathy" was coined for transcriptional ion channel modification developing postnatally (Waxman 2001). Finally, a standard nomenclature for all channelopathies was proposed by D'Adamo and colleagues combining the channel name and the disease phenotype (e.g., "K $\mathrm{K}_{\mathrm{v}} 1.1$-channelepsy" for epilepsy caused by $\mathrm{K}_{\mathrm{v}} 1.1$ channel defect) (D’Adamo et al. 2013). Here, we concentrate on the K-channel abnormalities observed in tissue of epilepsy patients, which can be both adaptive and maladaptive (Wolfart and Laker 2015).

\section{Properties of Human Brain Tissue from Epilepsy Surgery}

Obviously, brain tissue of epilepsy patients can only be obtained from those disease forms that are treatable via surgical resection of an epileptogenic focus (Duncan 2011; Jobst and Cascino 2015). Furthermore, only those specimens that are resected en bloc are appropriate, and considerable tissue is destroyed during epilepsy surgery via ultrasonic aspiration (Zentner et al. 1995). The overwhelming majority of surgical tissue stems from anterior temporal lobe resections 
for the treatment of TLE; extratemporal excision of neocortical tissue is less frequent (de Tisi et al. 2011; Jobst and Cascino 2015). If neocortex is resected, it often contains brain tumors such as gliomas, or maldeveloped tissue as in cortical dysplasia (Crino et al. 2002; de Tisi et al. 2011; Giulioni et al. 2014). It should be noted that many human tissue studies pool heterogeneous patient data. Here, we roughly group the studies into hippocampal and neocortical tissue.

About $90 \%$ of the hippocampi resected for treatment of epilepsy show hippocampal sclerosis (HS). This lesion, also called Ammon's horn sclerosis, is associated with the degeneration of CA1 pyramidal cells and other cell types especially in the hilus, as well as gliosis, sprouting of dentate gyrus (DG) granule cells and their dispersion (GCD) (Margerison and Corsellis 1966; Houser 1990; Wyler et al. 1992; Blümcke et al. 2012, 2013; Thom 2014). However, these sclerotic hippocampi are not entirely representative of TLE patients, because hippocampal atrophy itself positively influences the decision for surgery (Jobst and Cascino 2015). About $50 \%$ of all TLE patients show HS (Thom et al. 2010). To cope with the lack of control tissue, many studies compare severe versus mild HS specimens (Williamson and Patrylo 2007). However, the decision of whether no HS, mild HS, or severe HS exists is necessarily based on vague classification schemes (Wyler et al. 1992). Morphological studies can use autopsy samples as controls but this tissue harbors other hitches such as unequal immunogenicity and age matching. Thus, in view of the many studies concluding that epileptiform hyperexcitability results from CA1 cells in TLE animal models, it should be kept in mind that this region is depleted in about half of the TLE patients and consequently not very excitable (Cohen et al. 2002). In other words, dead cells are unlikely to seize (Delorenzo et al. 2005).

\section{Voltage-Gated Potassium Channels}

The most notorious example of an acquired Kchannelopathy, the down-regulation of $\mathrm{K}_{\mathrm{v}} 4.2 \mathrm{~A}$ type channels in dendrites of CA1 pyramidal cells in an animal model of TLE (Bernard et al. 2004; but see Monaghan et al. 2008; Su et al. 2008) has not yet been confirmed in tissue of TLE patients. In contrast, the CA pyramidal cells of TLE patients express ample $\mathrm{K}_{\mathrm{v}} 4.2$ protein, and quantification did not confirm lower amounts, despite the loss of pyramidal cells in this area. A Western blot analysis of human HS tissue even shows an increase of $\mathrm{K}_{\mathrm{v}} 4.2$ protein in TLE patients with HS compared with those without HS (Aronica et al. 2009). From this, it appears unlikely that TLE patients suffer from a $\mathrm{K}_{\mathrm{v}} 4.2$ channelopathy. Little data exists on other $\mathrm{K}_{\mathrm{v}}$ channels. No changes in $\mathrm{K}_{\mathrm{v}} 7.5$ immunostaining were detected in the temporal cortex of TLE patients versus autopsy samples (Yus-Najera et al. 2003). In neocortical tissue of five patients with TLE versus brain trauma, a regulatory protein that increases the influence of $\mathrm{K}_{\mathrm{v}} 1.1$ channels was found reduced; however, this effect was ascribed to interneurons ( $\mathrm{Li}$ et al. 2012).

Because of the above-described cell degeneration, the surviving DG granule cells have become the most frequently studied human cell type. The passive physiological properties of granule cells from TLE patients have been considered relatively similar to those of rodent granule cells (Williamson et al. 1993; Beck et al. 1996; Isokawa 1996b; Dietrich et al. 1999). On the other hand, abnormal properties of human granule cells have also been reported (Isokawa 1996a; Magloczky et al. 1997; de Lanerolle et al. 2003; Selke et al. 2006; Stegen et al. 2009, 2012). For example, it was described that a subpopulation of granule cells from HS tissue displays a hyperexcitable electrophysiology caused by faster AHPs and ensuing reduced spike frequency adaptation (Dietrich et al. 1999). $\mathrm{K}_{\mathrm{Ca}}$ channels could be responsible for this difference, but this remains undetermined. In another currentclamp study of human granule cells, pharmacological block of $\mathrm{K}_{\mathrm{v}} 7$ channels caused spike frequency acceleration, but it was concluded that $\mathrm{K}_{\mathrm{v}} 7$ channels do not contribute to the medium AHP of granule cells (Selke et al. 2006).

\section{Inward Rectifier Potassium Channels}

A reduced input resistance of human DG granule cells, caused by increased $\mathrm{K}_{\mathrm{ir}}$ resting con- 
ductances in severe versus mild HS specimen, suggested that these cells are rather hypo- than hyperexcitable (Stegen et al. 2009). Others failed to detect such currents in human granule cells altogether (Beck et al. 1997). This difference could be because of the fact that the latter study used cells dissociated from their dendrites, whereas the former study used intact neurons. Later recordings confirmed the decreased excitability of HS granule cells and revealed that it was caused by enhanced expression of $\mathrm{K}_{\mathrm{ir}} 2$ channels and hyperpolarization-activated cation (HCN1) channels (Stegen et al. 2012). Also a relative decrease in $\mathrm{K}_{\mathrm{ir}}$ currents in the astrocytes of the CA1 stratum radiatum of TLE patients with severe versus mild HS was determined (Hinterkeuser et al. 2000). The responsible channels are most likely $\mathrm{K}_{\mathrm{ir}} 4.1$ channels because they appeared down-regulated in respective samples at the protein level (Heuser et al. 2012). This impairment of glial $\mathrm{K}$ buffering capacity is the last thing needed in seizureaffected tissue, in which accumulation of $[\mathrm{K}]_{\mathrm{o}}$ is exceedingly high (Bordey and Sontheimer 1998; Kivi et al. 2000). Worse, the $\mathrm{E}_{\mathrm{K}}$ shift could depolarize $\mathrm{V}_{\text {rest }}$ of neighboring neurons. Therefore, glial $\mathrm{K}_{\mathrm{ir}}$-channelopathy is a potential mechanism for the seizure susceptibility in TLE (Jabs et al. 2008). On the other hand, too much $\mathrm{K}_{\mathrm{ir}} 4.1$ could also have proconvulsive effects (Sicca et al. 2011).

\section{ACQUIRED CHANGES IN SEIZURE/EPILEPSY MODELS}

\section{Models of Epilepsy}

There are two entirely different goals for the study of animal models of epilepsy. In industrial AED testing, the goal is to screen novel molecules for their antiseizure potential; examples are maximal electroshock and i.p. pentylenetetrazol, which are proven successful, in particular with respect to AEDs against generalized epilepsies (Löscher et al. 2013). In academic research, the goal is to simulate the anatomical and physiological symptoms of human epilepsy as precisely as possible (Coulter et al. 2002; Morimoto et al. 2004). Because one hypothesis for TLE is an initial precipitating injury (Mathern et al. 2002), many TLE models induce a status epilepticus (SE), which is then followed by chronic epilepsy. Examples are i.p. injection of kainate (Ben-Ari 1985) or pilocarpine (Turski et al. 1989), both of which produce generalized seizures but little HS (Curia et al. 2014). In contrast, SE, followed by focal seizures and HS, are induced by intrahippocampal kainate injections (Fritschy 2004). Perforant path stimulation-induced SE produces chronic bilateral seizures and HS (Bumanglag and Sloviter 2008), whereas electrical "kindling" of amygdala or hippocampus triggers seizures primarily during the stimulation without a chronic epilepsy and HS (Morimoto et al. 2004). It is also possible to acutely trigger seizure-like activity in vitro via pharmacological manipulations (Avoli et al. 2002). Finally, computational models can simulate seizure activity (Case and Soltesz 2011), but obviously the parameters have to be experimentally constrained as much as possible, because many things can produce runaway excitation in neuronal networks. Thus, all epilepsy models have advantages and disadvantages; the choice depends on the study aim.

In contrast to human epilepsy, it is clear that in animals that become epileptic after an epileptogenic insult, channel modifications are acquired; it is not clear whether the changes are causal or consequential to seizures, and whether observed channel changes are adaptive (counteracting hyperexcitability) or maladaptive (supporting hyperexcitability). Obviously, these scenarios may occur simultaneously. The most attractive changes may be the maladaptive ones, as they are considered to be, at least partly, causal to the seizures or even the disease development.

\section{Voltage-Gated Potassium Channels}

A computational model with features of the TLE network (Thomas et al. 2009) found that shifting the voltage-dependence of $\mathrm{K}_{\mathrm{v}} 1.1$ channels was the second-most potent (after $\mathrm{Na}_{\mathrm{v}}$ channels) in reducing high-frequency sustained firing in the network. The question is whether 
the AP frequency has a real link to the epilepsy of patients. Taking an alternative perspective and asking which type of activity A-type channels could perturb best, another computational study concluded that it is a highly synchronized activity (Fransen and Tigerholm 2010)—again, the link to epilepsy is vague. Adding another twist to this story, desynchronization by $\mathrm{K}_{\mathrm{v}}$ channel blockade might foster high-frequency oscillations/fast ripples that are a hallmark of seizure-like activity (Köhling and Staley 2011). There is also a strong case for adaptive $\mathrm{K}_{\mathrm{v}} 1$ channel changes occurring after SE (Meier et al. 2015; Wolfart and Laker 2015). In the intrahippocampal kainate model of TLE, the delay current, mediated by $\mathrm{K}_{\mathrm{v}} 1$ channels, is elevated (Kirchheim et al. 2013). Single-cell polymerase chain reaction (PCR) revealed that transcriptional up-regulation of $\mathrm{K}_{\mathrm{v}} 1.1$ subunits is responsible for this reversible adaptive reaction (Kirchheim et al. 2013). Another study showed that in a systemic kainate model, $\mathrm{K}_{\mathrm{v}} 1.1$ becomes less sensitive to blockade (by 4-AP) because of differential RNA editing-a change that protects against 4-AP-induced seizure-like events (in vitro, in the entorhinal cortex) (Streit et al. 2011).

Regarding A-type channels, one study suggested a $\mathrm{K}_{\mathrm{v}} 3.4$ protein down-regulation in hippocampi of pilocarpine-injected rats (Pacheco Otalora et al. 2011). Many epilepsy studies addressed alterations of $\mathrm{K}_{\mathrm{v}} 4.2$ channels. After systemic kainate injection, $\mathrm{K}_{\mathrm{v}} 4.2$ channels were decreased for a day in some regions (DG, CA3, CA4), but unchanged in other regions (CA1) (Francis et al. 1997). In pilocarpineinjected rats, the AP backpropagating into the dendrite is increased and less sensitive to $5 \mathrm{~mm}$ 4-AP in CA1 pyramidal cells and this corresponds to a decrease of $\mathrm{K}_{\mathrm{v}} 4.2$ (and $\mathrm{K}_{\mathrm{v}} 1.4$ ) mRNA in microdissected hippocampi (Bernard et al. 2004). Immunohistochemical studies confirmed some of these results but also showed conflicting data (Monaghan et al. 2008; Su et al. 2008). Again, the $K_{v} 4.2$ levels were either only transiently decreased or appeared even increased (Francis et al. 1997; Su et al. 2008). In the systemic kainate model, a decrease of $\mathrm{K}_{\mathrm{v}} 4.2$ in synaptosomes was described and also inter- preted as proepileptic mechanism (Lugo et al. 2008). However, this presynaptic effect could actually dampen fast firing and reduce transmitter release. On the other hand, down-regulation of hippocampal $K_{v} 4.2$ was also found to occur chronically after severe traumatic brain injury and in hypoxia epilepsy models (Lei et al. 2012; Peng et al. 2013). In addition to quantitative changes of $\mathrm{K}$ channels, pilocarpine SE may also induce a rapid (in $2 \mathrm{~h}$ ) redistribution of $\mathrm{K}_{\mathrm{v}} 4.2$ channels, as has been shown for thalamocortical neurons (Smith et al. 2012). Importantly, cardiac $\mathrm{K}_{\mathrm{v}} 4.2$ channels are also down-regulated in the pilocarpine model (Bealer et al. 2010). As these are critical for cardiomyocyte repolarization, arrhythmias arise within 2-wk post-SE.

Concerning $\mathrm{K}_{\mathrm{v}} 7$ channels, the channels that carry the most prominent mutations among patients, it is interesting to note that in the pilocarpine model, a decreased expression in dendrites (of the subiculum) has been shown for $\mathrm{K}_{\mathrm{v}} 7.2$ and $\mathrm{K}_{\mathrm{v}} 7.3$ (Maslarova et al. 2013). In the amygdala, $\mathrm{K}_{\mathrm{v}} 7.2$ channels appear down-regulated after kindling-induced seizures (Penschuck et al. 2005).

\section{Calcium- and Sodium-Activated Potassium Channels}

Another maladaptive channelopathy scenario associated with TLE models appears in recent publications regarding $\mathrm{K}_{\mathrm{Ca}}$ channels. Thus, BK- channel expression is down-regulated particularly in the $\mathrm{CA} 3$ region of pilocarpine-injected rats as determined by immunohistochemistry (Pacheco Otalora et al. 2008). This phenomenon is perhaps linked to the fact that the splice variant STREX is up-regulated, which leads to lower channel expression (Ermolinsky et al. 2011). Although this would confer increased calcium sensitivity to the remaining channels, the functional outcome seems to be that action potential firing is increased (Mehranfard et al. 2015). The contrary can be the case as well. In juvenile tissue of a picrotoxin epilepsy model, BK currents appear up-regulated-and associated with increased firing (Shruti et al. 2008). Another interesting group of $\mathrm{K}_{\mathrm{Ca}}$ channels are the SK channels that 
mediate part of the mAHP in many cell types; these channels can thus control excitability for hundreds of milliseconds and shape synchronization and timing of epileptiform activity (Fernandez de Sevilla et al. 2006). Both at the protein and the transcript level, SK2 (and SK3) channels were reduced after pilocarpine SE for up to 2 mo (Oliveira et al. 2010; Schulz et al. 2012). This has functional consequences. Inhibiting SK channels leads to massive exacerbation of epileptiform activity in hippocampal slices of chronically epileptic rats but not in control tissue (Schulz et al. 2012). Not only is the mAHP reduced in this tissue, but also the sAHP (Brehme et al. 2014). The mAHP reduction can be restored by blocking casein-kinase 2 (CK2), a major kinase for calmodulin phosphorylation. Because the phosphorylation of calmodulin in turn reduces SK calcium sensitivity, and because these channels are candidates for the SAHP, the restoration and normalization of the sAHP could be mediated by a normalization of SK-channel function. Intriguingly, chronic CK2 blockade renders hippocampal tissue resistant to induction of epileptiform activity in vitro (Brehme et al. 2014), opening up a novel therapeutic strategy. Even when epileptiform activity is induced in vitro via GABA-receptor blocker gabazine (within $2 \mathrm{~h}$ ), a reduction of the AHP can be observed, which can be reverted by protein kinase $\mathrm{A}$ (PKA) block (Kernig et al. 2012). Because SK channels (in particular SK2) are subject to PKA-induced ubiquitination and contribute to the AHP, it is plausible that the AHP reduction is caused by activity-dependent SK-channel phosphorylation and, possibly, internalization/ubiquitination (Kernig et al. 2012). On a more speculative basis, using a network model with neuronal properties from dorsal root ganglion cells, seizure termination was brought about by modulating SLACK $\left(\mathrm{K}_{\mathrm{Ca}} 4.1\right)$ currents (Krishnan and Bazhenov 2011; Igelstrom 2013).

\section{Inward Rectifier and Two Pore Domain Potassium Channels}

An acquired K-channel pattern that is highly likely to be adaptive and that matches the hu- man condition concerns $K_{\mathrm{ir}} 2$ channels. In the intrahippocampal kainate model of TLE, $\mathrm{K}_{\mathrm{ir}} 2$ currents are strongly increased in HS-affected DG granule cells, thus stabilizing $\mathrm{V}_{\text {rest }}$ and reducing the input resistance and intrinsic excitability significantly (Young et al. 2009). Concomitantly, the entire $\mathrm{K}_{\mathrm{ir}} 2$ family $\left(\mathrm{K}_{\mathrm{ir}} 2.1, \mathrm{~K}_{\mathrm{ir}} 2.2\right.$, $\mathrm{K}_{\mathrm{ir}} 2.3$, and $\left.\mathrm{K}_{\mathrm{ir}} 2.4\right)$ as well as the $\mathrm{K}_{2 \mathrm{P}}$ channels TWIK1 $\left(\mathrm{K}_{2 \mathrm{P}} 1.1\right)$ and TWIK2 $\left(\mathrm{K}_{2 \mathrm{P}} 6.1\right.$, but not $\mathrm{K}_{\mathrm{ir}} 3.2$ channels) were found to be chronically up-regulated in these cells (Young et al. 2009). Immunohistochemical studies, using the pilocarpine model, detect enhanced TASK channel signals in hippocampal tissue (Kim et al. 2009), which could be because of astrocytes (Kim et al. 2011). The $K_{\text {ir }} 6.2$ channels were found reduced in the DG and the frontal cortex in a less frequently used model of limbic picrotoxin kindling; however, this expression change lasts only $12 \mathrm{~h}$ and its functional implications are still unclear (Jiang et al. 2007).

Apart from neuronal channels, astrocytic $\mathrm{K}$ channels deserve a close analysis-after all, not only do mutations in astrocytic $\mathrm{K}_{\mathrm{ir}} 4.1$ channels occur in humans, but, also in genetic models, alterations in expression lead to epilepsy (see above). In the pilocarpine model of TLE, upregulation of $K_{\text {ir }} 4.1$ was reported, arguing for an adaptive change (Nagao et al. 2013). However, this is in strong contrast to human TLE, in which there is also functional evidence of reduced spatial buffering (Kivi et al. 2000). A study on the traumatic brain injury model in rats supports the maladaptive hypothesis, and perhaps also helps to clarify the discrepancies found between the TLE model and human TLE. In traumatic brain injury, a loss of $\mathrm{K}_{\mathrm{ir}}$ current occurs predominantly in the processes of astrocytes and not in their somata (Stewart et al. 2010). Hence, the functional aspect of spatial buffering warrants further investigation-A global expression change may mask a critical change on the functionally relevant processes.

A counterintuitive mechanism that has to be mentioned in the context of $\mathrm{K}$ buffering is depolarization block (of $\mathrm{Na}_{\mathrm{v}}$ and $\mathrm{Ca}_{\mathrm{v}}$ channels) by rising $[\mathrm{K}]_{\mathrm{o}}$. Although medium to high levels of depolarization can bring neurons closer 
to the AP threshold-perhaps the reason why aquaporin knockout animals have seizures, because this also alters their extracellular potassium handling (Binder et al. 2006)—too much depolarization could also drive excitatory channels in inactivation and thereby stop seizures. However, contesting views hold that it may not be so relevant (Bikson et al. 2003). Thus, the effect of K-channel activation depends on the actual $[\mathrm{K}]_{\mathrm{o}}$ level (Köhling and Staley 2011). Glial $\mathrm{K}$ buffering via $\mathrm{K}_{\mathrm{ir}} 4.1$ channels may thus be instrumental in controlling seizures. All in all, from these theoretical considerations, neuronal $\mathrm{K}_{\mathrm{v}} 1, \mathrm{~K}_{\mathrm{v}} 4$, and $\mathrm{K}_{\mathrm{Ca}}$, as well as glial $\mathrm{K}_{\mathrm{ir}}$ channels, should be attractive modulation candidates.

\section{INSIGHTS FROM ANTIEPILEPTIC DRUG RESEARCH}

Epilepsy is a threshold phenomenon. Most of the time seizures do not occur. Therefore, the best AED is one that only slightly shifts the seizure threshold. Targeting specific K channels could be a strategy to achieve just that (Wolfart and Laker 2015).

\section{Voltage-Activated Potassium Channels}

In many in vitro situations, a K-channel opening can stop seizure-like activity. This is particularly expected when this activity was itself evoked via a K-channel block (Gandolfo et al. 1989). However, in contrast to $\mathrm{Na}_{\mathrm{v}}$ and $\mathrm{Ca}_{\mathrm{v}}$ channels (Köhling 2002; Löscher et al. 2013), only one K-channel opener (retigabine) is approved as an AED mechanism of action (Faulkner and Burke 2013). This drug shifts the availability of $K_{v} 7.2$ and $\mathrm{K}_{\mathrm{v}} 7.3$ channels to more hyperpolarized potentials, such that they are active already at $\mathrm{V}_{\text {rest }}$ (Main et al. 2000; Rundfeldt and Netzer 2000; Wickenden et al. 2000). Coincidentally, retigabine fulfills a major criterion for AEDs. It is specific for the neuronal forms of $\mathrm{K}_{\mathrm{v}} 7\left(\mathrm{~K}_{\mathrm{v}} 7.2\right.$, $\left.\mathrm{K}_{\mathrm{v}} 7.3, \mathrm{~K}_{\mathrm{v}} 7.5\right)$ and does not affect the cardiac $\mathrm{K}_{\mathrm{v}} 7.1$ channel (Tatulian et al. 2001; Schenzer et al. 2005). Subsequently, many $\mathrm{K}_{\mathrm{v}} 7$ openers have been synthesized (Peretz et al. 2005; Wu and Dworetzky 2005; Roeloffs et al. 2008; Wick- enden et al. 2008; Raol et al. 2009), but future research needs to determine whether and how patients could benefit from such AEDs (Splinter 2013).

Other $\mathrm{K}_{\mathrm{v}}$ channels have also been considered as targets not only for AEDs but also for gene therapy approaches. For example, in an animal model of focal (neocortical) epilepsy, viral overexpression of neocortical pyramidal cells with $\mathrm{K}_{\mathrm{v}} 1.1$ channels reduced epileptic seizures (Wykes et al. 2012). Also, a pharmacological block of regulatory protein target of rapamycin (mTOR), which maintains elevated levels of $\mathrm{K}_{\mathrm{v}} 1.1$ channels, is effective against experimental seizures (Sosanya et al. 2014). Another promising antiseizure strategy is to prolong the inactivation of $\mathrm{K}_{\mathrm{v}} 1$ channels conferred by $\mathrm{K}_{\mathrm{v}} \beta 1.1$ via “disinactivator" substances ( $\mathrm{Lu}$ et al. 2008).

The activation of $\mathrm{K}_{\mathrm{Ca}}$ channels, although in principle successful against experimental seizures, had considerable side effects in standard AED testing models, ruling out clinical use so far (Anderson et al. 2006).

\section{Inward Rectifier Potassium Channels}

Several $K_{i r}$ channels have been tested as potential AEDs, and some of the already approved AEDs have retrospectively been shown to additionally open $K_{i r}$ channels. For example, the AED pregabaline opens $K_{\mathrm{ir}} 6.2\left(\mathrm{~K}_{\mathrm{ATP}}\right)$ channels (Huang et al. 2006). However, in conventional AED screening models, $\mathrm{K}_{\mathrm{ir}} 6$-targeting AEDs have proven ineffective (Wickenden 2002). In this context, it is also worth noting that the approved AED pregabaline also activates $\mathrm{K}_{\mathrm{ir}} 1.1$ channels, which may be responsible for heartrelated side effects (Lee and Liou 2014). The proposal that $\mathrm{K}_{\mathrm{ir}} 2$ channels could function as antiepileptic channels (Young et al. 2009; Wolfart and Laker 2015) is supported by the finding that the anti-inflammatory drug tenidap, which was found to open $\mathrm{K}_{\mathrm{ir}} 2.3$ channels (Liu et al. 2002), is also quite effective in abolishing epileptic seizures in standard AED testing models (Xu et al. 2013). Also, $\mathrm{K}_{\mathrm{ir}} 3$ channel activation may be an AED strategy as suggested by a barium-sensitive component of the effect of AED 
gabapentin (Bertrand et al. 2003) and by a synthetic $\mathrm{K}_{\mathrm{ir}} 3\left(\mathrm{~K}_{\mathrm{ir}} 3.1, \mathrm{~K}_{\mathrm{v}} 3.2\right.$ and $\left.\mathrm{K}_{\mathrm{ir}} 3.1, \mathrm{~K}_{\mathrm{v}} 3.4\right)$ channel activator that yielded an antiseizure result comparable to approved AEDs (Kaufmann et al. 2013).

\section{Potassium Channel-Inhibiting Antiepileptic Drugs}

Certainly, AEDs were not designed to inhibit K channels, and unless one is able to specifically target $\mathrm{K}$ channels in inhibitory neurons, this effect will likely not be a goal of AED research. Nevertheless, certain effective AEDs do block K channels, and thus may indeed be preferentially acting on GABAergic interneurons, or could contribute to unwanted side effects (Danielsson et al. 2003, 2005; but see Meldrum and Rogawski 2007). Examples are lamotrigine inhibiting various $\mathrm{K}_{\mathrm{v}}$ currents (Grunze et al. 1998; Huang et al. 2004), ethosuximide blocking BK channels (Crunelli and Leresche 2002), and levetiracetam reducing delayed rectifier $\mathrm{K}$ currents (Madeja et al. 2003).

\section{ACKNOWLEDGMENTS}

J.W. is funded via Grant WO1563/1-1 of the Deutsche Forschungsgemeinschaft (DFG). R.K. is funded by BfArM Grant Z121.03-2246-V14415.

\section{REFERENCES}

Alexander SP, Benson HE, Faccenda E, Pawson AJ, Sharman JL, Catterall WA, Spedding M, Peters JA, Harmar AJ, Collaborators C. 2013. The concise guide to pharmacology 2013/14: Ion channels. Br J Pharmacol 170: 16071651.

Anderson PA, Greenberg RM. 2001. Phylogeny of ion channels: Clues to structure and function. Comp Biochem Physiol B Biochem Mol Biol 129: 17-28.

Anderson NJ, Slough S, Watson WP. 2006. In vivo characterisation of the small-conductance $\mathrm{K}_{\mathrm{Ca}}(\mathrm{SK})$ channel activator 1-ethyl-2-benzimidazolinone (1-EBIO) as a potential anticonvulsant. Eur J Pharmacol 546: 48-53.

Aronica E, Boer K, Doorn KJ, Zurolo E, Spliet WG, van Rijen PC, Baayen JC, Gorter JA, Jeromin A. 2009. Expression and localization of voltage dependent potassium channel $\mathrm{K}_{\mathrm{v}} 4.2$ in epilepsy associated focal lesions. Neurobiol Dis 36: $81-95$
Avoli M, D’Antuono M, Louvel J, Köhling R, Biagini G, Pumain R, D’Arcangelo G, Tancredi V. 2002. Network and pharmacological mechanisms leading to epileptiform synchronization in the limbic system in vitro. Prog Neurobiol 68: 167-207.

Barhanin J, Lesage F, Guillemare E, Fink M, Lazdunski M, Romey G. 1996. K $\mathrm{V}$ LQT1 and IsK (minK) proteins associate to form the $I_{\mathrm{KS}}$ cardiac potassium current. Nature 384: $78-80$.

Barnwell LF, Lugo JN, Lee WL, Willis SE, Gertz SJ, Hrachovy RA, Anderson AE. 2009. $K_{\mathrm{v}} 4.2$ knockout mice demonstrate increased susceptibility to convulsant stimulation. Epilepsia 50: 1741-1751.

Bealer SL, Little JG, Metcalf CS, Brewster AL, Anderson AE. 2010. Autonomic and cellular mechanisms mediating detrimental cardiac effects of status epilepticus. Epilepsy Res 91: 66-73.

Beck H, Blumcke I, Kral T, Clusmann H, Schramm J, Wiestler OD, Heinemann U, Elger CE. 1996. Properties of a delayed rectifier potassium current in dentate granule cells isolated from the hippocampus of patients with chronic temporal lobe epilepsy. Epilepsia 37: 892-901.

Beck H, Clusmann H, Kral T, Schramm J, Heinemann U, Elger CE. 1997. Potassium currents in acutely isolated human hippocampal dentate granule cells. J Physiol 498: $73-85$.

Ben-Ari Y. 1985. Limbic seizure and brain damage produced by kainic acid: Mechanisms and relevance to human temporal lobe epilepsy. Neuroscience 14: 375-403.

Bernard C, Anderson A, Becker A, Poolos NP, Beck H, Johnston D. 2004. Acquired dendritic channelopathy in temporal lobe epilepsy. Science 305: 532-535.

Bertrand S, Nouel D, Morin F, Nagy F, Lacaille JC. 2003 Gabapentin actions on Kir3 currents and N-type $\mathrm{Ca}^{2+}$ channels via $\mathrm{GABA}_{\mathrm{B}}$ receptors in hippocampal pyramidal cells. Synapse 50: 95-109.

Bhattacharjee A, Kaczmarek LK. 2005. For $\mathrm{K}^{+}$channels, $\mathrm{Na}^{+}$is the new $\mathrm{Ca}^{2+}$. Trends Neurosci 28: 422-428.

Biervert C, Schroeder BC, Kubisch C, Berkovic SF, Propping P, Jentsch TJ, Steinlein OK. 1998. A potassium channel mutation in neonatal human epilepsy. Science 279: 403-406.

Bikson M, Hahn PJ, Fox JE, Jefferys JG. 2003. Depolarization block of neurons during maintenance of electrographic seizures. J Neurophysiol 90: 2402-2408.

Binder DK, Yao X, Zador Z, Sick TJ, Verkman AS, Manley GT. 2006. Increased seizure duration and slowed potassium kinetics in mice lacking aquaporin-4 water channels. Glia 53: 631-636.

Blümcke I, Coras R, Miyata H, Ozkara C. 2012. Defining clinico-neuropathological subtypes of mesial temporal lobe epilepsy with hippocampal sclerosis. Brain Pathol 22: $402-411$.

Blümcke I, Thom M, Aronica E, Armstrong DD, Bartolomei F, Bernasconi A, Bernasconi N, Bien CG, Cendes F, Coras $\mathrm{R}$, et al. 2013. International consensus classification of hippocampal sclerosis in temporal lobe epilepsy: A Task Force report from the ILAE Commission on Diagnostic Methods. Epilepsia 54: 1315-1329.

Bockenhauer D, Feather S, Stanescu HC, Bandulik S, Zdebik AA, Reichold M, Tobin J, Lieberer E, Sterner C, Landoure 
G, et al. 2009. Epilepsy, ataxia, sensorineural deafness, tubulopathy, and KCNJ10 mutations. N Engl J Med 360: $1960-1970$

Bordey A, Sontheimer H. 1998. Properties of human glial cells associated with epileptic seizure foci. Epilepsy Res 32: $286-303$.

Brehme H, Kirschstein T, Schulz R, Köhling R. 2014. In vivo treatment with the casein kinase 2 inhibitor 4,5,6,7-tetrabromotriazole augments the slow after-hyperpolarizing potential and prevents acute epileptiform activity. Epilepsia 55: 175-183.

Brenner R, Wilcox KS. 2012. Potassium channelopathies of epilepsy. In Jasper's basic mechanisms of the epilepsies (ed. Noebels JL, Avoli M, Rogawski MA, Olsen RW, DelgadoEscueta $\mathrm{AV}$ ). National Center for Biotechnology Information, Bethesda, MD.

Brenner R, Jegla TJ, Wickenden A, Liu Y, Aldrich RW. 2000. Cloning and functional characterization of novel large conductance calcium-activated potassium channel $\beta$ subunits, hKCNMB3 and hKCNMB4. J Biol Chem 275: 6453-6461.

Brenner R, Chen QH, Vilaythong A, Toney GM, Noebels JL, Aldrich RW. 2005. BK channel $\beta 4$ subunit reduces dentate gyrus excitability and protects against temporal lobe seizures. Nat Neurosci 8: 1752-1759.

Brew HM, Gittelman JX, Silverstein RS, Hanks TD, Demas VP, Robinson LC, Robbins CA, McKee-Johnson J, Chiu SY, Messing A, et al. 2007. Seizures and reduced life span in mice lacking the potassium channel subunit $\mathrm{K}_{\mathrm{v}} 1.2$, but hypoexcitability and enlarged $\mathrm{K}_{\mathrm{v}} 1$ currents in auditory neurons. J Neurophysiol 98: 1501-1525.

Bumanglag AV, Sloviter RS. 2008. Minimal latency to hippocampal epileptogenesis and clinical epilepsy after perforant pathway stimulation-induced status epilepticus in awake rats. J Comp Neurol 510: 561-580.

Buono RJ, Lohoff FW, Sander T, Sperling MR, O’Connor MJ, Dlugos DJ, Ryan SG, Golden GT, Zhao H, Scattergood TM, et al. 2004. Association between variation in the human KCNJ10 potassium ion channel gene and seizure susceptibility. Epilepsy Res 58: 175-183.

Butt AM, Kalsi A. 2006. Inwardly rectifying potassium channels $\left(\mathrm{K}_{\mathrm{ir}}\right)$ in central nervous system glia: A special role for $\mathrm{K}_{\mathrm{ir}} 4.1$ in glial functions. J Cell Mol Med 10: 33-44.

Case M, Soltesz I. 2011. Computational modeling of epilepsy. Epilepsia 52: 12-15.

Charlier C, Singh NA, Ryan SG, Lewis TB, Reus BE, Leach RJ, Leppert M. 1998. A pore mutation in a novel KQT-like potassium channel gene in an idiopathic epilepsy family. Nat Genet 18: 53-55.

Coetzee WA, Amarillo Y, Chiu J, Chow A, Lau D, McCormack T, Moreno H, Nadal MS, Ozaita A, Pountney D, et al. 1999. Molecular diversity of $\mathrm{K}^{+}$channels. Ann NY Acad Sci 868: 233-285.

Cohen I, Navarro V, Clemenceau S, Baulac M, Miles R. 2002. On the origin of interictal activity in human temporal lobe epilepsy in vitro. Science 298: 1418-1421.

Connor JA, Stevens CF. 1971. Voltage clamp studies of a transient outward membrane current in gastropod neural somata. J Physiol 213: 21-30.
Coulter DA, McIntyre DC, Löscher W. 2002. Animal models of limbic epilepsies: What can they tell us? Brain Pathol 12: $240-256$.

Crino PB, Miyata H, Vinters HV. 2002. Neurodevelopmental disorders as a cause of seizures: Neuropathologic, genetic, and mechanistic considerations. Brain Pathol 12: 212-233.

Crunelli V, Leresche N. 2002. Block of thalamic T-type $\mathrm{Ca}^{2+}$ channels by ethosuximide is not the whole story. Epilepsy Curr 2: 53-56.

Curia G, Lucchi C, Vinet J, Gualtieri F, Marinelli C, Torsello A, Costantino L, Biagini G. 2014. Pathophysiogenesis of mesial temporal lobe epilepsy: Is prevention of damage antiepileptogenic? Curr Med Chem 21: 663-688.

D’Adamo MC, Catacuzzeno L, Di Giovanni G, Franciolini F, Pessia M. 2013. $\mathrm{K}^{+}$channelepsy: Progress in the neurobiology of potassium channels and epilepsy. Front Cell Neurosci 7: 134.

Danielsson BR, Lansdell K, Patmore L, Tomson T. 2003. Phenytoin and phenobarbital inhibit human HERG potassium channels. Epilepsy Res 55: 147-157.

Danielsson BR, Lansdell K, Patmore L, Tomson T. 2005. Effects of the antiepileptic drugs lamotrigine, topiramate and gabapentin on hERG potassium currents. Epilepsy Res 63: 17-25.

de Lanerolle NC, Kim JH, Williamson A, Spencer SS, Zaveri HP, Eid T, Spencer DD. 2003. A retrospective analysis of hippocampal pathology in human temporal lobe epilepsy: Evidence for distinctive patient subcategories. Epilepsia 44: 677-687.

Delorenzo RJ, Sun DA, Deshpande LS. 2005. Cellular mechanisms underlying acquired epilepsy: The calcium hypothesis of the induction and maintenance of epilepsy. Pharmacol Ther 105: 229-266.

de Tisi J, Bell GS, Peacock JL, McEvoy AW, Harkness WF Sander JW, Duncan JS. 2011. The long-term outcome of adult epilepsy surgery, patterns of seizure remission, and relapse: A cohort study. Lancet 378: 1388-1395.

Dietrich D, Clusmann H, Kral T, Steinhauser C, Blumcke I, Heinemann U, Schramm J. 1999. Two electrophysiologically distinct types of granule cells in epileptic human hippocampus. Neuroscience 90: 1197-1206.

Djukic B, Casper KB, Philpot BD, Chin LS, McCarthy KD. 2007. Conditional knock-out of $K_{\mathrm{ir}} 4.1$ leads to glial membrane depolarization, inhibition of potassium and glutamate uptake, and enhanced short-term synaptic potentiation. J Neurosci 27: 11354-11365.

Donahue LR, Cook SA, Johnson KR, Bronson RT, Davisson MT. 1996. Megencephaly: A new mouse mutation on chromosome 6 that causes hypertrophy of the brain. Mamm Genome 7: 871-876.

Du W, Bautista JF, Yang H, Diez-Sampedro A, You SA, Wang L, Kotagal P, Luders HO, Shi J, Cui J, et al. 2005. Calciumsensitive potassium channelopathy in human epilepsy and paroxysmal movement disorder. Nat Genet 37: 733-738.

Duncan JS. 2011. Selecting patients for epilepsy surgery: Synthesis of data. Epilepsy Behav 20: 230-232.

Ermolinsky BS, Skinner F, Garcia I, Arshadmansab MF, Otalora LF, Zarei MM, Garrido-Sanabria ER. 2011. Upregulation of STREX splice variant of the large conductance 
$\mathrm{Ca}^{2+}$-activated potassium (BK) channel in a rat model of mesial temporal lobe epilepsy. Neurosci Res 69: 73-80.

Faulkner MA, Burke RA. 2013. Safety profile of two novel antiepileptic agents approved for the treatment of refractory partial seizures: Ezogabine (retigabine) and perampanel. Exp Opin Drug Safety 12: 847-855.

Fernandez de Sevilla D, Garduno J, Galvan E, Buno W. 2006 Calcium-activated after-hyperpolarizations regulate synchronization and timing of epileptiform bursts in hippocampal CA3 pyramidal neurons. J Neurophysiol 96: 3028-3041.

Ferraro TN, Golden GT, Smith GG, Martin JF, Lohoff FW, Gieringer TA, Zamboni D, Schwebel CL, Press DM, Kratzer SO, et al. 2004. Fine mapping of a seizure susceptibility locus on mouse chromosome 1: Nomination of Kcnj10 as a causative gene. Mamm Genome 15: 239-251.

Francis J, Jugloff DG, Mingo NS, Wallace MC, Jones OT Burnham WM, Eubanks JH. 1997. Kainic acid-induced generalized seizures alter the regional hippocampal expression of the rat $\mathrm{K}_{\mathrm{v}} 4.2$ potassium channel gene. Neurosci Lett 232: 91-94.

Fransen E, Tigerholm J. 2010. Role of A-type potassium currents in excitability, network synchronicity, and epilepsy. Hippocampus 20: 877-887.

Fritschy JM. 2004. A new animal model of temporal lobe epilepsy. Epileptologie 21-28.

Gandolfo G, Gottesmann C, Bidard JN, Lazdunski M. 1989. Subtypes of $\mathrm{K}^{+}$channels differentiated by the effect of $\mathrm{K}^{+}$ channel openers upon $\mathrm{K}^{+}$channel blocker-induced seizures. Brain Res 495: 189-192.

George AL Jr. 2004. Inherited channelopathies associated with epilepsy. Epilepsy Curr 4: 65-70.

Giulioni M, Marucci G, Martinoni M, Marliani AF, Toni F, Bartiromo F, Volpi L, Riguzzi P, Bisulli F, Naldi I, et al. 2014. Epilepsy associated tumors: Review article. World J Clin Cases 2: 623-641.

Glasscock E, Qian J, Yoo JW, Noebels JL. 2007. Masking epilepsy by combining two epilepsy genes. Nat Neurosci 10: $1554-1558$.

Glasscock E, Yoo JW, Chen TT, Klassen TL, Noebels JL. 2010. $\mathrm{K}_{\mathrm{v}} 1.1$ potassium channel deficiency reveals brain-driven cardiac dysfunction as a candidate mechanism for sudden unexplained death in epilepsy. J Neurosci 30: 51675175.

Goldman AM, Glasscock E, Yoo J, Chen TT, Klassen TL, Noebels JL. 2009. Arrhythmia in heart and brain: KCNQ1 mutations link epilepsy and sudden unexplained death. Sci Transl Med 1: 2ra6.

Goldstein SA, Bockenhauer D, O'Kelly I, Zilberberg N. 2001. Potassium leak channels and the KCNK family of two-P-domain subunits. Nat Rev Neurosci 2: 175-184.

Goldstein SA, Bayliss DA, Kim D, Lesage F, Plant LD, Rajan S. 2005. International Union of Pharmacology. LV: Nomenclature and molecular relationships of two-P potassium channels. Pharmacol Rev 57: 527-540.

Gower WR. 1881. Epilepsy and other chronic convulsive disorders, their causes, symptoms and treatment. J \& A Churchill, London.

Grissmer S, Nguyen AN, Aiyar J, Hanson DC, Mather RJ, Gutman GA, Karmilowicz MJ, Auperin DD, Chandy KG. 1994. Pharmacological characterization of five cloned voltage-gated $\mathrm{K}^{+}$channels, types $\mathrm{K}_{\mathrm{v}} 1.1,1.2,1.3,1.5$, and 3.1, stably expressed in mammalian cell lines. $\mathrm{Mol}$ Pharmacol 45: 1227-1234.

Grunze H, von Wegerer J, Greene RW, Walden J. 1998. Modulation of calcium and potassium currents by lamotrigine. Neuropsychobiology 38: 131-138.

Grupe A, Schroter KH, Ruppersberg JP, Stocker M, Drewes T, Beckh S, Pongs O. 1990. Cloning and expression of a human voltage-gated potassium channel. A novel member of the RCK potassium channel family. EMBO J 9: 1749-1756.

Gu N, Vervaeke K, Storm JF. 2007. BK potassium channels facilitate high-frequency firing and cause early spike frequency adaptation in rat CA1 hippocampal pyramidal cells. J Physiol 580: 859-882.

Gutman GA, Chandy KG, Grissmer S, Lazdunski M, McKinnon D, Pardo LA, Robertson GA, Rudy B, Sanguinetti MC, Stuhmer W, et al. 2005. International Union of Pharmacology. LIII: Nomenclature and molecular relationships of voltage-gated potassium channels. Pharmacol Rev 57: 473-508.

Harada Y, Nagao Y, Shimizu S, Serikawa T, Terada R, Fujimoto M, Okuda A, Mukai T, Sasa M, Kurachi Y, et al. 2013. Expressional analysis of inwardly rectifying $K_{\mathrm{ir}} 4.1$ channels in Noda epileptic rat (NER). Brain Res 1517: 141-149.

Haruna Y, Kobori A, Makiyama T, Yoshida H, Akao M, Doi T, Tsuji K, Ono S, Nishio Y, Shimizu W, et al. 2007. Genotype-phenotype correlations of KCNJ2 mutations in Japanese patients with Andersen-Tawil syndrome. Hum Mutat 28: 208.

Hattersley AT, Ashcroft FM. 2005. Activating mutations in $\mathrm{K}_{\mathrm{ir}} 6.2$ and neonatal diabetes: New clinical syndromes, new scientific insights, and new therapy. Diabetes 54: 2503-2513.

Hatton WJ, Mason HS, Carl A, Doherty P, Latten MJ, Kenyon JL, Sanders KM, Horowitz B. 2001. Functional and molecular expression of a voltage-dependent $\mathrm{K}^{+}$channel $\left(\mathrm{K}_{\mathrm{v}} 1.1\right)$ in interstitial cells of Cajal. J Physiol 533: $315-$ 327.

Heron SE, Smith KR, Bahlo M, Nobili L, Kahana E, Licchetta L, Oliver KL, Mazarib A, Afawi Z, Korczyn A, et al. 2012. Missense mutations in the sodium-gated potassium channel gene KCNT1 cause severe autosomal dominant nocturnal frontal lobe epilepsy. Nat Genet 44: $1188-1190$.

Heuser K, Nagelhus EA, Tauboll E, Indahl U, Berg PR, Lien S, Nakken S, Gjerstad L, Ottersen OP. 2010. Variants of the genes encoding AQP4 and $K_{\text {ir }} 4.1$ are associated with subgroups of patients with temporal lobe epilepsy. Epilepsy Res 88: 55-64.

Heuser K, Eid T, Lauritzen F, Thoren AE, Vindedal GF, Tauboll E, Gjerstad L, Spencer DD, Ottersen OP, Nagelhus EA, et al. 2012. Loss of perivascular $\mathrm{K}_{\mathrm{ir}} 4.1$ potassium channels in the sclerotic hippocampus of patients with mesial temporal lobe epilepsy. J Neuropathol Exp Neurol 71: 814-825.

Higashi K, Fujita A, Inanobe A, Tanemoto M, Doi K, Kubo T, Kurachi Y. 2001. An inwardly rectifying $\mathrm{K}^{+}$channel, $\mathrm{K}_{\mathrm{ir}} 4.1$, expressed in astrocytes surrounds synapses and blood vessels in brain. Am J Physiol Cell Physiol 281: C922-C931. 
Hille B. 2001. Ion channels of excitable membranes. Sinauer, Sunderland, MA.

Hinterkeuser S, Schroder W, Hager G, Seifert G, Blumcke I, Elger CE, Schramm J, Steinhauser C. 2000. Astrocytes in the hippocampus of patients with temporal lobe epilepsy display changes in potassium conductances. Eur J Neurosci 12: 2087-2096.

Hodgkin AL, Huxley AF. 1952. Currents carried by sodium and potassium ions through the membrane of the giant axon of Loligo. J Physiol 116: 449-472.

Holter J, Carter D, Leresche N, Crunelli V, Vincent P. 2005. A TASK3 channel (KCNK9) mutation in a genetic model of absence epilepsy. J Mol Neurosci 25: 37-51.

Houser CR. 1990. Granule cell dispersion in the dentate gyrus of humans with temporal lobe epilepsy. Brain Res 535: 195-204.

Hu HJ, Carrasquillo Y, Karim F, Jung WE, Nerbonne JM, Schwarz TL, Gereau RW IV. 2006. The $\mathrm{k}_{\mathrm{v}} 4.2$ potassium channel subunit is required for pain plasticity. Neuron 50: $89-100$.

Huang CW, Huang CC, Liu YC, Wu SN. 2004. Inhibitory effect of lamotrigine on A-type potassium current in hippocampal neuron-derived H19-7 cells. Epilepsia 45: $729-736$.

Huang CW, Huang CC, Wu SN. 2006. The opening effect of pregabalin on ATP-sensitive potassium channels in differentiated hippocampal neuron-derived H19-7 cells. Epilepsia 47: 720-726.

Igelstrom KM. 2013. Is slack an intrinsic seizure terminator? Neuroscientist 19: 248-254.

Inyushin M, Kucheryavykh LY, Kucheryavykh YV, Nichols CG, Buono RJ, Ferraro TN, Skatchkov SN, Eaton MJ. 2010. Potassium channel activity and glutamate uptake are impaired in astrocytes of seizure-susceptible DBA/2 mice. Epilepsia 51: 1707-1713.

Ishida S, Sakamoto Y, Nishio T, Baulac S, Kuwamura M, Ohno Y, Takizawa A, Kaneko S, Serikawa T, Mashimo T. 2012. Kcna1-mutant rats dominantly display myokymia, neuromyotonia and spontaneous epileptic seizures. Brain Res 1435: 154-166.

Isokawa M. 1996a. Decreased time constant in hippocampal dentate granule cells in pilocarpine-treated rats with progressive seizure frequencies. Brain Res 718: 169-175.

Isokawa M. 1996b. Decrement of GABA $A_{A}$ receptor-mediated inhibitory postsynaptic currents in dentate granule cells in epileptic hippocampus. J Neurophysiol 75: 1901-1908.

Isomoto S, Kondo C, Kurachi Y. 1997. Inwardly rectifying potassium channels: Their molecular heterogeneity and function. Jpn J Physiol 47: 11-39.

Jabs R, Seifert G, Steinhauser C. 2008. Astrocytic function and its alteration in the epileptic brain. Epilepsia 49: $3-$ 12

Jentsch TJ. 2000. Neuronal KCNQ potassium channels: Physiology and role in disease. Nat Rev Neurosci 1: 21 30

Jiang K, Yu Z, Shui Q. 2007. The pattern of ATP-sensitive $\mathrm{K}^{+}$ channel subunits, $\mathrm{K}_{\mathrm{ir}} 6.2$ and SUR1 mRNA expressions in DG region is different from those in CA1-3 regions of chronic epilepsy induced by picrotoxin in rats. Neuropathology 27: 531-538.
Jobst BC, Cascino GD. 2015. Resective epilepsy surgery for drug-resistant focal epilepsy: A review. JAMA 313: 285 293.

Jorge BS, Campbell CM, Miller AR, Rutter ED, Gurnett CA, Vanoye CG, George AL Jr, Kearney JA. 2011. Voltagegated potassium channel KCNV2 (Kv8.2) contributes to epilepsy susceptibility. Proc Natl Acad Sci 108: 54435448.

Kalachikov S, Evgrafov O, Ross B, Winawer M, Barker-Cummings C, Martinelli Boneschi F, Choi C, Morozov P, Das $\mathrm{K}$, Teplitskaya E, et al. 2002. Mutations in LGI1 cause autosomal-dominant partial epilepsy with auditory features. Nat Genet 30: 335-341.

Kaufmann K, Romaine I, Days E, Pascual C, Malik A, Yang L, Zou B, Du Y, Sliwoski G, Morrison RD, et al. 2013. ML297 (VU0456810), the first potent and selective activator of the GIRK potassium channel, displays antiepileptic properties in mice. ACS Chem Neurosci 4: 12781286.

Kearney JA, Yang Y, Beyer B, Bergren SK, Claes L, Dejonghe P, Frankel WN. 2006. Severe epilepsy resulting from genetic interaction between Scn2a and Kcnq2. Hum Mol Genet 15: 1043-1048.

Kernig K, Kirschstein T, Wurdemann T, Rohde M, Köhling R. 2012. The after-hyperpolarizing potential following a train of action potentials is suppressed in an acute epilepsy model in the rat Cornu Ammonis 1 area. Neuroscience 201: 288-296.

Kim DS, Kim JE, Kwak SE, Choi HC, Song HK, Kimg YI, Choi SY, Kang TC. 2007. Up-regulated astroglial TWIKrelated acid-sensitive $\mathrm{K}^{+}$channel-1 (TASK-1) in the hippocampus of seizure-sensitive gerbils: A target of antiepileptic drugs. Brain Res 1185: 346-358.

Kim JE, Kwak SE, Kang TC. 2009. Upregulated TWIK-related acid-sensitive $\mathrm{K}^{+}$channel-2 in neurons and perivascular astrocytes in the hippocampus of experimental temporal lobe epilepsy. Epilepsia 50: 654-663.

Kim JE, Yeo SI, Ryu HJ, Chung CK, Kim MJ, Kang TC. 2011. Changes in TWIK-related acid sensitive $\mathrm{K}^{+}-1$ and -3 channel expressions from neurons to glia in the hippocampus of temporal lobe epilepsy patients and experimental animal model. Neurochem Res 36: 2155-2168.

Kirchheim F, Tinnes S, Haas CA, Stegen M, Wolfart J. 2013 Regulation of action potential delays via voltage-gated potassium $\mathrm{K}_{\mathrm{v}} 1.1$ channels in dentate granule cells during hippocampal epilepsy. Front Cell Neurosci 7: 248.

Kivi A, Lehmann TN, Kovacs R, Eilers A, Jauch R, Meencke HJ, von Deimling A, Heinemann U, Gabriel S. 2000 Effects of barium on stimulus-induced rises of $\left[\mathrm{K}^{+}\right]_{\mathrm{o}}$ in human epileptic non-sclerotic and sclerotic hippocampal area CA1. Eur J Neurosci 12: 2039-2048.

Köhling R. 2002. Voltage-gated sodium channels in epilepsy. Epilepsia 43: 1278-1295.

Köhling R, Staley K. 2011. Network mechanisms for fast ripple activity in epileptic tissue. Epilepsy Res 97: 318323.

Krishnan GP, Bazhenov M. 2011. Ionic dynamics mediate spontaneous termination of seizures and postictal depression state. J Neurosci 31: 8870-8882.

Kubo Y, Adelman JP, Clapham DE, Jan LY, Karschin A, Kurachi Y, Lazdunski M, Nichols CG, Seino S, Vandenberg CA. 2005. International Union of Pharmacology. LIV: 
R. Köhling and J. Wolfart

Nomenclature and molecular relationships of inwardly rectifying potassium channels. Pharmacol Rev 57: 509526.

Kullmann DM. 2002. The neuronal channelopathies. Brain 125: $1177-1195$

Lau D, Vega-Saenz de Miera EC, Contreras D, Ozaita A, Harvey M, Chow A, Noebels JL, Paylor R, Morgan JI, Leonard CS, et al. 2000. Impaired fast-spiking, suppressed cortical inhibition, and increased susceptibility to seizures in mice lacking $\mathrm{K}_{\mathrm{v}} 3.2 \mathrm{~K}^{+}$channel proteins. $J$ Neurosci 20: 9071-9085.

Lee CH, Liou HH. 2014. Pregabalin activates ROMK1 channels via cAMP-dependent protein kinase and protein kinase C. Eur J Pharmacol 740: 35-44.

Lee SM, Kim JE, Sohn JH, Choi HC, Lee JS, Kim SH, Kim MJ, Choi IG, Kang TC. 2009. Down-regulation of delayed rectifier $\mathrm{K}^{+}$channels in the hippocampus of seizure sensitive gerbils. Brain Res Bull 80: 433-442.

Lei Z, Deng P, Li J, Xu ZC. 2012. Alterations of A-type potassium channels in hippocampal neurons after traumatic brain injury. J Neurotrauma 29: 235-245.

Leonard AS, Hyder SN, Kolls BJ, Arehart E, Ng KC, Veerapandiyan A, Mikati MA. 2013. Seizure predisposition after perinatal hypoxia: Effects of subsequent age and of an epilepsy predisposing gene mutation. Epilepsia 54: 1789-1800.

Lerche H, Shah M, Beck H, Noebels J, Johnston D, Vincent A. 2013. Ion channels in genetic and acquired forms of epilepsy. J Physiol 591: 753-764.

Lesage F, Lazdunski M. 2000. Molecular and functional properties of two-pore-domain potassium channels. Am J Physiol Renal Physiol 279: F793-F801.

Li KX, Lu YM, Xu ZH, Zhang J, Zhu JM, Zhang JM, Cao SX, Chen XJ, Chen Z, Luo JH, et al. 2012. Neuregulin 1 regulates excitability of fast-spiking neurons through $\mathrm{K}_{\mathrm{v}} 1.1$ and acts in epilepsy. Nat Neurosci 15: 267-273.

Lippiat JD, Standen NB, Harrow ID, Phillips SC, Davies NW. 2003. Properties of $\mathrm{BK}_{\mathrm{Ca}}$ channels formed by bicistronic expression of $h$ Slo $\alpha$ and $\beta 1-4$ subunits in HEK293 cells. J Membr Biol 192: 141-148.

Liu Y, Liu D, Printzenhoff D, Coghlan MJ, Harris R, Krafte DS. 2002. Tenidap, a novel anti-inflammatory agent, is an opener of the inwardly rectifying $\mathrm{K}^{+}$channel hKir2.3. Eur J Pharmacol 435: 153-160.

Löscher W, Klitgaard H, Twyman RE, Schmidt D. 2013. New avenues for anti-epileptic drug discovery and development. Nat Rev Drug Discov 12: 757-776.

Lu Q, Peevey J, Jow F, Monaghan MM, Mendoza G, Zhang H, Wu J, Kim CY, Bicksler J, Greenblatt L, et al. 2008. Disruption of $\mathrm{K}_{\mathrm{v}} 1.1 \mathrm{~N}$-type inactivation by novel small molecule inhibitors (disinactivators). Bioorganic Med Chem 16: 3067-3075.

Lugo JN, Barnwell LF, Ren Y, Lee WL, Johnston LD, Kim R, Hrachovy RA, Sweatt JD, Anderson AE. 2008. Altered phosphorylation and localization of the A-type channel, $\mathrm{K}_{v} 4.2$ in status epilepticus. J Neurochem 106: 1929-1940.

Madeja M, Margineanu DG, Gorji A, Siep E, Boerrigter P, Klitgaard H, Speckmann EJ. 2003. Reduction of voltageoperated potassium currents by levetiracetam: A novel antiepileptic mechanism of action? Neuropharmacology 45: 661-671.
Magloczky Z, Halasz P, Vajda J, Czirjak S, Freund TF. 1997. Loss of calbindin-D28K immunoreactivity from dentate granule cells in human temporal lobe epilepsy. Neuroscience 76: $377-385$.

Main MJ, Cryan JE, Dupere JR, Cox B, Clare JJ, Burbidge SA. 2000. Modulation of KCNQ2/3 potassium channels by the novel anticonvulsant retigabine. Mol Pharmacol 58: 253-262.

Margerison JH, Corsellis JA. 1966. Epilepsy and the temporal lobes. A clinical, electroencephalographic and neuropathological study of the brain in epilepsy, with particular reference to the temporal lobes. Brain 89: 499-530.

Maslarova A, Salar S, Lapilover E, Friedman A, Veh RW, Heinemann U. 2013. Increased susceptibility to acetylcholine in the entorhinal cortex of pilocarpine-treated rats involves alterations in KCNQ channels. Neurobiol Dis 56: $14-24$.

Mathern GW, Adelson PD, Cahan LD, Leite JP. 2002. Hippocampal neuron damage in human epilepsy: Meyer's hypothesis revisited. Prog Brain Res 135: 237-251.

Mehranfard N, Gholamipour-Badie H, Motamedi F, Janahmadi M, Naderi N. 2015. Long-term increases in BK potassium channel underlie increased action potential firing in dentate granule neurons following pilocarpineinduced status epilepticus in rats. Neurosci Lett 585: 88-91.

Meier J, Semtner M, Wolfart J. 2015. Homeostasis of neuronal excitability via synaptic and intrinsic inhibitory mechanisms. In Homeostatic control of brain function (ed. Boison D, Masino SA). Oxford University Press, Oxford.

Meldrum BS, Rogawski MA. 2007. Molecular targets for antiepileptic drug development. Neurotherapeutics 4: 18 61.

Miceli F, Striano P, Soldovieri MV, Fontana A, Nardello R, Robbiano A, Bellini G, Elia M, Zara F, Taglialatela M, et al. 2015. A novel KCNQ3 mutation in familial epilepsy with focal seizures and intellectual disability. Epilepsia 56: e15-e20.

Mirkovic K, Palmersheim J, Lesage F, Wickman K. 2012. Behavioral characterization of mice lacking Trek channels. Front Behav Neurosci 6: 60 .

Monaghan MM, Trimmer JS, Rhodes KJ. 2001. Experimental localization of Kv1 family voltage-gated $\mathrm{K}^{+}$channel $\alpha$ and $\beta$ subunits in rat hippocampal formation. J Neurosci 21: 5973-5983.

Monaghan MM, Menegola M, Vacher H, Rhodes KJ, Trimmer JS. 2008. Altered expression and localization of hippocampal A-type potassium channel subunits in the pilocarpine-induced model of temporal lobe epilepsy. Neuroscience 156: 550-562.

Moore BM, Jerry Jou C, Tatalovic M, Kaufman ES, Kline DD, Kunze DL. 2014. The $\mathrm{K}_{\mathrm{v}} 1.1$ null mouse, a model of sudden unexpected death in epilepsy (SUDEP). Epilepsia 55: $1808-1816$.

Morimoto K, Fahnestock M, Racine RJ. 2004. Kindling and status epilepticus models of epilepsy: Rewiring the brain. Prog Neurobiol 73: 1-60.

Mulley JC, Scheffer IE, Petrou S, Berkovic SF. 2003. Channelopathies as a genetic cause of epilepsy. Curr Opin $\mathrm{Neu}$ rol 16: 171-176. 
Muona M, Berkovic SF, Dibbens LM, Oliver KL, Maljevic S, Bayly MA, Joensuu T, Canafoglia L, Franceschetti S, Michelucci R, et al. 2015. A recurrent de novo mutation in $\mathrm{KCNC1}$ causes progressive myoclonus epilepsy. $\mathrm{Nat} \mathrm{Ge}$ net 47: 39-46.

Nagao Y, Harada Y, Mukai T, Shimizu S, Okuda A, Fujimoto M, Ono A, Sakagami Y, Ohno Y. 2013. Expressional analysis of the astrocytic $\mathrm{K}_{\mathrm{ir}} 4.1$ channel in a pilocarpine-induced temporal lobe epilepsy model. Front Cell Neurosci 7: 104 .

Neubauer BA, Waldegger S, Heinzinger J, Hahn A, Kurlemann G, Fiedler B, Eberhard F, Muhle H, Stephani U, Garkisch S, et al. 2008. KCNQ2 and KCNQ3 mutations contribute to different idiopathic epilepsy syndromes. Neurology 71: 177-183.

Neusch C, Papadopoulos N, Muller M, Maletzki I, Winter SM, Hirrlinger J, Handschuh M, Bahr M, Richter DW, Kirchhoff F, et al. 2006. Lack of the $\mathrm{K}_{\mathrm{ir}} 4.1$ channel subunit abolishes $\mathrm{K}^{+}$buffering properties of astrocytes in the ventral respiratory group: Impact on extracellular $\mathrm{K}^{+}$ regulation. J Neurophysiol 95: 1843-1852.

N'Gouemo P. 2011. Targeting BK (big potassium) channels in epilepsy. Exp Opin Ther Targets 15: 1283-1295.

Oliveira MS, Skinner F, Arshadmansab MF, Garcia I, Mello CF, Knaus HG, Ermolinsky BS, Otalora LF, GarridoSanabria ER. 2010. Altered expression and function of small-conductance (SK) $\mathrm{Ca}^{2+}$-activated $\mathrm{K}^{+}$channels in pilocarpine-treated epileptic rats. Brain Res 1348: $187-$ 199.

Olsen ML, Sontheimer H. 2008. Functional implications for $\mathrm{K}_{\mathrm{ir}} 4.1$ channels in glial biology: From $\mathrm{K}^{+}$buffering to cell differentiation. J Neurochem 107: 589-601.

Otto JF, Yang Y, Frankel WN, Wilcox KS, White HS. 2004. Mice carrying the Szt1 mutation exhibit increased seizure susceptibility and altered sensitivity to compounds acting at the M-channel. Epilepsia 45: 1009-1016.

Ozaita A, Martone ME, Ellisman MH, Rudy B. 2002. Differential subcellular localization of the two alternatively spliced isoforms of the $\mathrm{K}_{\mathrm{v}} 3.1$ potassium channel subunit in brain. J Neurophysiol 88: 394-408.

Pacheco Otalora LF, Hernandez EF, Arshadmansab MF, Francisco S, Willis M, Ermolinsky B, Zarei M, Knaus HG, Garrido-Sanabria ER. 2008. Down-regulation of BK channel expression in the pilocarpine model of temporal lobe epilepsy. Brain Res 1200: 116-131.

Pacheco Otalora LF, Skinner F, Oliveira MS, Farrell B, Arshadmansab MF, Pandari T, Garcia I, Robles L, Rosas G, Mello CF, et al. 2011. Chronic deficit in the expression of voltage-gated potassium channel Kv3.4 subunit in the hippocampus of pilocarpine-treated epileptic rats. Brain Res 1368: 308-316.

Patil N, Cox DR, Bhat D, Faham M, Myers RM, Peterson AS 1995. A potassium channel mutation in weaver mice implicates membrane excitability in granule cell differentiation. Nat Genet 11: 126-129.

Pedroarena CM. 2011. BK and Kv3.1 potassium channels control different aspects of deep cerebellar nuclear neurons action potentials and spiking activity. Cerebellum 10: $647-658$

Peng BW, Justice JA, He XH, Sanchez RM. 2013. Decreased A-currents in hippocampal dentate granule cells after seizure-inducing hypoxia in the immature rat. Epilepsia 54: $1223-1231$.

Penschuck S, Bastlund JF, Jensen HS, Stensbol TB, Egebjerg J, Watson WP. 2005. Changes in KCNQ2 immunoreactivity in the amygdala in two rat models of temporal lobe epilepsy. Brain Res Mol Brain Res 141: 66-73.

Peretz A, Degani N, Nachman R, Uziyel Y, Gibor G, Shabat D, Attali B. 2005. Meclofenamic acid and diclofenac, novel templates of KCNQ2/Q3 potassium channel openers, depress cortical neuron activity and exhibit anticonvulsant properties. Mol Pharmacol 67: 1053-1066.

Perkowski JJ, Murphy GG. 2011. Deletion of the mouse homolog of KCNAB2, a gene linked to monosomy $1 \mathrm{p} 36$, results in associative memory impairments and amygdala hyperexcitability. J Neurosci 31: 46-54.

Peters HC, Hu H, Pongs O, Storm JF, Isbrandt D. 2005. Conditional transgenic suppression of $\mathrm{M}$ channels in mouse brain reveals functions in neuronal excitability, resonance and behavior. Nat Neurosci 8: 51-60.

Petersson S, Persson AS, Johansen JE, Ingvar M, Nilsson J, Klement G, Arhem P, Schalling M, Lavebratt C. 2003. Truncation of the Shaker-like voltage-gated potassium channel, $\mathrm{K}_{\mathrm{v}} 1.1$, causes megencephaly. Eur J Neurosci 18: 3231-3240.

Pongs O, Kecskemethy N, Muller R, Krah-Jentgens I, Baumann A, Kiltz HH, Canal I, Llamazares S, Ferrus A. 1988. Shaker encodes a family of putative potassium channel proteins in the nervous system of Drosophila. EMBO J 7: 1087-1096.

Qi Y, Wang J, Bomben VC, Li DP, Chen SR, Sun H, Xi Y, Reed JG, Cheng J, Pan HL, et al. 2014. Hyper-SUMOylation of the $\mathrm{K}_{\mathrm{v}} 7$ potassium channel diminishes the M-current leading to seizures and sudden death. Neuron 83: 1159-1171.

Raol YH, Lapides DA, Keating JG, Brooks-Kayal AR, Cooper EC. 2009. A KCNQ channel opener for experimenta neonatal seizures and status epilepticus. Ann Neurol 65: 326-336.

Rettig J, Wunder F, Stocker M, Lichtinghagen R, Mastiaux F, Beckh S, Kues W, Pedarzani P, Schroter KH, Ruppersberg JP, et al. 1992. Characterization of a Shaw-related potassium channel family in rat brain. EMBO J 11: 2473-2486.

Rettig J, Heinemann SH, Wunder F, Lorra C, Parcej DN, Dolly JO, Pongs O. 1994. Inactivation properties of voltage-gated $\mathrm{K}^{+}$channels altered by presence of $\beta$-subunit. Nature 369: 289-294.

Rhodes KJ, Strassle BW, Monaghan MM, Bekele-Arcuri Z, Matos MF, Trimmer JS. 1997. Association and colocalization of the $K_{v} \beta 1$ and $K_{v} \beta 2 \beta$-subunits with $K_{v} 1 \alpha$-subunits in mammalian brain $\mathrm{K}^{+}$channel complexes. J Neurosci 17: 8246-8258.

Rhodes KJ, Carroll KI, Sung MA, Doliveira LC, Monaghan MM, Burke SL, Strassle BW, Buchwalder L, Menegola M Cao J, et al. 2004. KChIPs and $\mathrm{K}_{\mathrm{v}} 4 \alpha$ subunits as integral components of A-type potassium channels in mammalian brain. J Neurosci 24: 7903-7915.

Riazanski V, Becker A, Chen J, Sochivko D, Lie A, Wiestler OD, Elger CE, Beck H. 2001. Functional and molecular analysis of transient voltage-dependent $\mathrm{K}^{+}$currents in rat hippocampal granule cells. J Physiol 537: 391-406. 
Robbins CA, Tempel BL. 2012. $\mathrm{K}_{\mathrm{v}} 1.1$ and $\mathrm{K}_{\mathrm{v}} 1.2$ : Similar channels, different seizure models. Epilepsia 53: 134141.

Roeloffs R, Wickenden AD, Crean C, Werness S, McNaughton-Smith G, Stables J, McNamara JO, Ghodadra N, Rigdon GC. 2008. In vivo profile of ICA-27243 [N-(6chloro-pyridin-3-yl)-3,4-difluoro-benzamide], a potent and selective KCNQ2/Q3 $\left(\mathrm{K}_{\mathrm{v}} 7.2 / \mathrm{K}_{\mathrm{v}} 7.3\right)$ activator in rodent anticonvulsant models. J Pharmacol Exp Ther 326: $818-828$.

Rundfeldt C, Netzer R. 2000. The novel anticonvulsant retigabine activates $\mathrm{M}$-currents in Chinese hamster ovarycells transfected with human KCNQ2/3 subunits. Neurosci Lett 282: 73-76.

Ruppersberg JP, Schroter KH, Sakmann B, Stocker M, Sewing S, Pongs O. 1990. Heteromultimeric channels formed by rat brain potassium-channel proteins. Nature 345: 535-537.

Sah P, Faber ES. 2002. Channels underlying neuronal calcium-activated potassium currents. Prog Neurobiol 66: 345-353.

Sanguinetti MC. 2010. HERG1 channelopathies. Pflugers Arch 460: 265-276.

Schenzer A, Friedrich T, Pusch M, Saftig P, Jentsch TJ, Grotzinger J, Schwake M. 2005. Molecular determinants of $\mathrm{KCNQ}\left(\mathrm{K}_{\mathrm{v}} 7\right) \mathrm{K}^{+}$channel sensitivity to the anticonvulsant retigabine. J Neurosci 25: 5051-5060.

Scholl UI, Choi M, Liu T, Ramaekers VT, Hausler MG, Grimmer J, Tobe SW, Farhi A, Nelson-Williams C, Lifton RP. 2009. Seizures, sensorineural deafness, ataxia, mental retardation, and electrolyte imbalance (SeSAME syndrome) caused by mutations in KCNJ10. Proc Natl Acad Sci 106: 5842-5847.

Schroeder BC, Kubisch C, Stein V, Jentsch TJ. 1998. Moderate loss of function of cyclic-AMP-modulated KCNQ2/KCNQ3 $\mathrm{K}^{+}$channels causes epilepsy. Nature 396: 687-690.

Schulz R, Kirschstein T, Brehme H, Porath K, Mikkat U, Köhling R. 2012. Network excitability in a model of chronic temporal lobe epilepsy critically depends on SK channel-mediated AHP currents. Neurobiol Dis 45: 337347.

Selke K, Muller A, Kukley M, Schramm J, Dietrich D. 2006. Firing pattern and calbindin-D28k content of human epileptic granule cells. Brain Res 1120: 191-201.

Shah P, Demirbilek H, Hussain K. 2014. Persistent hyperinsulinaemic hypoglycaemia in infancy. Semin Pediatr Surg 23: 76-82.

Sheng M, Tsaur ML, Jan YN, Jan LY. 1994. Contrasting subcellular localization of the $\mathrm{K}_{\mathrm{v}} 1.2 \mathrm{~K}^{+}$channel subunit in different neurons of rat brain. J Neurosci 14: 2408-2417.

Shruti S, Clem RL, Barth AL. 2008. A seizure-induced gainof-function in BK channels is associated with elevated firing activity in neocortical pyramidal neurons. Neurobiol Dis 30: 323-330.

Sicca F, Imbrici P, D'Adamo MC, Moro F, Bonatti F, Brovedani P, Grottesi A, Guerrini R, Masi G, Santorelli FM, et al. 2011. Autism with seizures and intellectual disability: Possible causative role of gain-of-function of the inwardly rectifying $\mathrm{K}^{+}$channel $\mathrm{K}_{\mathrm{ir}} 4.1$. Neurobiol Dis 43: 239247.
Signorini S, Liao YJ, Duncan SA, Jan LY, Stoffel M. 1997. Normal cerebellar development but susceptibility to seizures in mice labievcking $G$ protein-coupled, inwardly rectifying $\mathrm{K}^{+}$channel GIRK2. Proc Natl Acad Sci 94: 923-927.

Simeone TA, Simeone KA, Samson KK, Kim do Y, Rho JM. 2013. Loss of the $K_{v} 1.1$ potassium channel promotes pathologic sharp waves and high frequency oscillations in in vitro hippocampal slices. Neurobiol Dis 54: 68-81.

Simons C, Rash LD, Crawford J, Ma L, Cristofori-Armstrong B, Miller D, Ru K, Baillie GJ, Alanay Y, Jacquinet A, et al. 2015. Mutations in the voltage-gated potassium channel gene $\mathrm{KCNH} 1$ cause Temple-Baraitser syndrome and epilepsy. Nat Genet 47: 73-77.

Singh NA, Charlier C, Stauffer D, DuPont BR, Leach RJ, Melis R, Ronen GM, Bjerre I, Quattlebaum T, Murphy JV, et al. 1998. A novel potassium channel gene, KCNQ2, is mutated in an inherited epilepsy of newborns. Nat Genet 18: 25-29.

Singh B, Ogiwara I, Kaneda M, Tokonami N, Mazaki E, Baba K, Matsuda K, Inoue Y, Yamakawa K. 2006. A K 4.2 truncation mutation in a patient with temporal lobe epilepsy. Neurobiol Dis 24: 245-253.

Singh NA, Otto JF, Dahle EJ, Pappas C, Leslie JD, Vilaythong A, Noebels JL, White HS, Wilcox KS, Leppert MF. 2008 Mouse models of human KCNQ2 and KCNQ3 mutations for benign familial neonatal convulsions show seizures and neuronal plasticity without synaptic reorganization. J Physiol 586: 3405-3423.

Slesinger PA, Patil N, Liao YJ, Jan YN, Jan LY, Cox DR. 1996. Functional effects of the mouse weaver mutation on $G$ protein-gated inwardly rectifying $\mathrm{K}^{+}$channels. Neuron 16: $321-331$.

Slingerland AS, Hattersley AT. 2005. Mutations in the $\mathrm{K}_{\mathrm{ir}} 6.2$ subunit of the $\mathrm{K}_{\mathrm{ATP}}$ channel and permanent neonatal diabetes: New insights and new treatment. Ann Med 37: $186-195$.

Smart SL, Lopantsev V, Zhang CL, Robbins CA, Wang H, Chiu SY, Schwartzkroin PA, Messing A, Tempel BL. 1998. Deletion of the $\mathrm{K}_{\mathrm{V}} 1.1$ potassium channel causes epilepsy in mice. Neuron 20: 809-819.

Smith B, Robinson GC, Lennox WG. 1954. Acquired epilepsy; A study of 535 cases. Neurology 4: 19-28.

Smith SE, Xu L, Kasten MR, Anderson MP. 2012. Mutant LGI1 inhibits seizure-induced trafficking of $\mathrm{K}_{\mathrm{v}} 4.2$ potassium channels. J Neurochem 120: 611-621.

Soh H, Pant R, LoTurco JJ, Tzingounis AV. 2014. Conditional deletions of epilepsy-associated KCNQ2 and KCNQ3 channels from cerebral cortex cause differential effects on neuronal excitability. J Neurosci 34: 5311-5321.

Soldovieri MV, Boutry-Kryza N, Milh M, Doummar D, Heron B, Bourel E, Ambrosino P, Miceli F, De Maria M, Dorison N, et al. 2014. Novel KCNQ2 and KCNQ3 mutations in a large cohort of families with benign neonatal epilepsy: First evidence for an altered channel regulation by syntaxin-1A. Hum Mutat 35: 356-367.

Sosanya NM, Brager DH, Wolfe S, Niere F, Raab-Graham KF. 2014. Rapamycin reveals an mTOR-independent repression of $\mathrm{K}_{\mathrm{v}} 1.1$ expression during epileptogenesis. Neurobiol Dis 73C: 96-105.

Soundarapandian MM, Wu D, Zhong X, Petralia RS, Peng L, Tu W, Lu Y. 2007. Expression of functional Kir6.1 chan- 
nels regulates glutamate release at CA3 synapses in generation of epileptic form of seizures. J Neurochem 103: 1982-1988.

Splinter MY. 2013. Efficacy of retigabine in adjunctive treatment of partial onset seizures in adults. J Cent Nerv Syst Dis 5: 31-41.

Stanfield PR, Nakajima S, Nakajima Y. 2002. Constitutively active and G-protein coupled inward rectifier $\mathrm{K}^{+}$channels: $\mathrm{K}_{\mathrm{ir}} 2.0$ and $\mathrm{K}_{\mathrm{ir}} 3.0$. Rev Physiol Biochem Pharmacol 145: $47-179$.

Stegen M, Young CC, Haas CA, Zentner J, Wolfart J. 2009. Increased leak conductance in dentate gyrus granule cells of temporal lobe epilepsy patients with Ammon's horn sclerosis. Epilepsia 50: 646-653.

Stegen M, Kirchheim F, Hanuschkin A, Staszewski O, Veh RW, Wolfart J. 2012. Adaptive intrinsic plasticity in human dentate gyrus granule cells during temporal lobe epilepsy. Cereb Cortex 22: 2087-2101.

Steinlein OK. 2004. Genetic mechanisms that underlie epilepsy. Nat Rev Neurosci 5: 400-408.

Stewart TH, Eastman CL, Groblewski PA, Fender JS, Verley DR, Cook DG, D'Ambrosio R. 2010. Chronic dysfunction of astrocytic inwardly rectifying $\mathrm{K}^{+}$channels specific to the neocortical epileptic focus after fluid percussion injury in the rat. J Neurophysiol 104: 3345-3360.

Storm JF. 1988. Temporal integration by a slowly inactivating $\mathrm{K}^{+}$current in hippocampal neurons. Nature 336: 379-381.

Streit AK, Derst C, Wegner S, Heinemann U, Zahn RK, Decher N. 2011. RNA editing of $K_{v} 1.1$ channels may account for reduced ictogenic potential of 4-aminopyridine in chronic epileptic rats. Epilepsia 52: 645-648.

Stuhmer W, Ruppersberg JP, Schroter KH, Sakmann B, Stocker M, Giese KP, Perschke A, Baumann A, Pongs O. 1989. Molecular basis of functional diversity of voltagegated potassium channels in mammalian brain. EMBO J 8: $3235-3244$.

Su T, Cong WD, Long YS, Luo AH, Sun WW, Deng WY, Liao WP. 2008. Altered expression of voltage-gated potassium channel 4.2 and voltage-gated potassium channel 4-interacting protein, and changes in intracellular calcium levels following lithium-pilocarpine-induced status epilepticus. Neuroscience 157: 566-576.

Sutherland ML, Williams SH, Abedi R, Overbeek PA, Pfaffinger PJ, Noebels JL. 1999. Overexpression of a Shakertype potassium channel in mammalian central nervous system dysregulates native potassium channel gene expression. Proc Natl Acad Sci 96: 2451-2455.

Syrbe S, Hedrich UB, Riesch E, Djemie T, Muller S, Moller RS, Maher B, Hernandez-Hernandez L, Synofzik M, Caglayan HS, et al. 2015. De novo loss- or gain-of-function mutations in KCNA2 cause epileptic encephalopathy. Nat Genet 47: 393-399.

Tatulian L, Delmas P, Abogadie FC, Brown DA. 2001. Activation of expressed KCNQ potassium currents and native neuronal M-type potassium currents by the anti-convulsant drug retigabine. J Neurosci 21: 5535-5545.

Thom M. 2014. Review: Hippocampal sclerosis in epilepsy: A neuropathology review. Neuropathol Appl Neurobiol 40: $520-543$.
Thom M, Mathern GW, Cross JH, Bertram EH. 2010. Mesial temporal lobe epilepsy: How do we improve surgical outcome? Ann Neurol 68: 424-434.

Thomas EA, Reid CA, Berkovic SF, Petrou S. 2009. Prediction by modeling that epilepsy may be caused by very small functional changes in ion channels. Arch Neurol 66: $1225-1232$.

Trimmer JS. 2015. Subcellular localization of $\mathrm{K}^{+}$channels in mammalian brain aneurons: Remarkable precision in the midst of extraordinary complexity. Neuron 85: 238-256.

Turski L, Ikonomidou C, Turski WA, Bortolotto ZA, Cavalheiro EA. 1989. Review: Cholinergic mechanisms and epileptogenesis. The seizures induced by pilocarpine: A novel experimental model of intractable epilepsy. Synapse 3: $154-171$.

VanDyke DH, Griggs RC, Murphy MJ, Goldstein MN. 1975. Hereditary myokymia and periodic ataxia. J Neurol Sci 25: 109-118.

Verma-Ahuja S, Evans MS, Pencek TL. 1995. Evidence for decreased calcium dependent potassium conductance in hippocampal CA3 neurons of genetically epilepsy-prone rats. Epilepsy Res 22: 137-144.

Wang J, Zhou J, Todorovic SM, Feero WG, Barany F, Conwit R, Hausmanowa-Petrusewicz I, Fidzianska A, Arahata K, Wessel HB, et al. 1993. Molecular genetic and genetic correlations in sodium channelopathies: Lack of founder effect and evidence for a second gene. Am J Hum Genet 52: 1074-1084.

Wang H, Kunkel DD, Schwartzkroin PA, Tempel BL. 1994. Localization of $\mathrm{K}_{\mathrm{v}} 1.1$ and $\mathrm{K}_{\mathrm{v}} 1.2$, two $\mathrm{K}$ channel proteins, to synaptic terminals, somata, and dendrites in the mouse brain. J Neurosci 14: 4588-4599.

Wang Q, Curran ME, Splawski I, Burn TC, Millholland JM, VanRaay TJ, Shen J, Timothy KW, Vincent GM, de Jager T, et al. 1996. Positional cloning of a novel potassium channel gene: KVLQT1 mutations cause cardiac arrhythmias. Nat Genet 12: 17-23.

Wang B, Rothberg BS, Brenner R. 2009. Mechanism of increased BK channel activation from a channel mutation that causes epilepsy. J Gen Physiol 133: 283-294.

Wang HG, He XP, Li Q, Madison RD, Moore SD, McNamara JO, Pitt GS. 2013. The auxiliary subunit KChIP2 is an essential regulator of homeostatic excitability. J Biol Chem 288: $13258-13268$.

Waxman SG. 2001. Transcriptional channelopathies: An emerging class of disorders. Nat Rev Neurosci 2: 652-659.

Weckhuysen S, Mandelstam S, Suls A, Audenaert D, Deconinck T, Claes LR, Deprez L, Smets K, Hristova D, Yordanova I, et al. 2012. KCNQ2 encephalopathy: Emerging phenotype of a neonatal epileptic encephalopathy. Ann Neurol 71: 15-25.

Weckhuysen S, Ivanovic V, Hendrickx R, Van Coster R, Hjalgrim H, Moller RS, Gronborg S, Schoonjans AS, Ceulemans B, Heavin SB, et al. 2013. Extending the KCNQ2 encephalopathy spectrum: Clinical and neuroimaging findings in 17 patients. Neurology 81: 1697-1703.

Wei AD, Gutman GA, Aldrich R, Chandy KG, Grissmer S, Wulff H. 2005. International Union of Pharmacology. LII: Nomenclature and molecular relationships of calcium-activated potassium channels. Pharmacol Rev 57: $463-472$. 
R. Köhling and J. Wolfart

Wenzel HJ, Vacher H, Clark E, Trimmer JS, Lee AL, Sapolsky RM, Tempel BL, Schwartzkroin PA. 2007. Structural consequences of Kcnal gene deletion and transfer in the mouse hippocampus. Epilepsia 48: 2023-2046.

Wickenden AD. 2002. Potassium channels as anti-epileptic drug targets. Neuropharmacology 43: 1055-1060.

Wickenden AD, Yu W, Zou A, Jegla T, Wagoner PK. 2000. Retigabine, a novel anti-convulsant, enhances activation of KCNQ2/Q3 potassium channels. Mol Pharmacol 58: 591-600.

Wickenden AD, Krajewski JL, London B, Wagoner PK, Wilson WA, Clark S, Roeloffs R, McNaughton-Smith G, Rigdon GC. 2008. N-(6-chloro-pyridin-3-yl)-3,4-difluorobenzamide (ICA-27243): A novel, selective KCNQ2/Q3 potassium channel activator. Mol Pharmacol 73: 977986.

Williamson A, Patrylo PR. 2007. Physiological studies of human dentate granule cells. Prog Brain Res 163: 183198.

Williamson A, Spencer DD, Shepherd GM. 1993. Comparison between the membrane and synaptic properties of human and rodent dentate granule cells. Brain Res 622: 194-202.

Wolfart J, Laker D. 2015. Homeostasis or channelopathy? Acquired cell type-specific ion channel changes in temporal lobe epilepsy and their antiepileptic potential. Front Physiol 6: 168 .

Wu YJ, Dworetzky SI. 2005. Recent developments on KCNQ potassium channel openers. Curr Med Chem 12: $453-$ 460.

Wykes RC, Heeroma JH, Mantoan L, Zheng K, MacDonald DC, Deisseroth K, Hashemi KS, Walker MC, Schorge S, Kullmann DM. 2012. Optogenetic and potassium channel gene therapy in a rodent model of focal neocortical epilepsy. Sci Transl Med 4: 161-152.

Wyler AR, Dohan FC, Schweitzer JB, Berry AD. 1992. A grading system for hippocampal sclerosis. J Epilepsy 5: $220-225$.

Xu L, Hao Y, Wu X, Yu P, Zhu G, Hong Z. 2013. Tenidap, an agonist of the inwardly rectifying $\mathrm{K}^{+}$channel Kir2.3, delays the onset of cortical epileptiform activity in a model of chronic temporal lobe epilepsy. Neurol Res 35: 561567.

Yamada K, Ji JJ, Yuan H, Miki T, Sato S, Horimoto N, Shimizu T, Seino S, Inagaki N. 2001. Protective role of ATPsensitive potassium channels in hypoxia-induced generalized seizure. Science 292: 1543-1546.
Yang Y, Beyer BJ, Otto JF, O’Brien TP, Letts VA, White HS, Frankel WN. 2003. Spontaneous deletion of epilepsy gene orthologs in a mutant mouse with a low electroconvulsive threshold. Hum Mol Genet 12: 975-984.

Yang J, Krishnamoorthy G, Saxena A, Zhang G, Shi J, Yang H, Delaloye K, Sept D, Cui J. 2010. An epilepsy/dyskinesia-associated mutation enhances BK channel activation by potentiating $\mathrm{Ca}^{2+}$ sensing. Neuron 66: 871-883.

Young CC, Stegen M, Bernard R, Muller M, Bischofberger J, Veh RW, Haas CA, Wolfart J. 2009. Upregulation of inward rectifier $\mathrm{K}^{+}\left(\mathrm{K}_{\mathrm{ir}} 2\right)$ channels in dentate gyrus granule cells in temporal lobe epilepsy. J Physiol 587: 4213-4233.

Yu FH, Yarov-Yarovoy V, Gutman GA, Catterall WA. 2005. Overview of molecular relationships in the voltage-gated ion channel superfamily. Pharmacol Rev 57: 387-395.

Yus-Najera E, Munoz A, Salvador N, Jensen BS, Rasmussen HB, Defelipe J, Villarroel A. 2003. Localization of KCNQ5 in the normal and epileptic human temporal neocortex and hippocampal formation. Neuroscience 120: 353-364.

Zamorano-Leon JJ, Yanez R, Jaime G, Rodriguez-Sierra P, Calatrava-Ledrado L, Alvarez-Granada RR, Mateos-Caceres PJ, Macaya C, Lopez-Farre AJ. 2012. KCNH2 gene mutation: A potential link between epilepsy and long QT2 syndrome. J Neurogenet 26: 382-386.

Zdebik AA, Mahmood F, Stanescu HC, Kleta R, Bockenhauer D, Russell C. 2013. Epilepsy in kcnj10 morphant zebrafish assessed with a novel method for long-term EEG recordings. PLoS ONE 8: e79765.

Zentner J, Hufnagel A, Wolf HK, Ostertun B, Behrens E, Campos MG, Solymosi L, Elger CE, Wiestler OD, Schramm J. 1995. Surgical treatment of temporal lobe epilepsy: Clinical, radiological, and histopathological findings in 178 patients. J Neurol Neurosurg Psychiatry 58: $666-673$.

Zhang X, Bertaso F, Yoo JW, Baumgartel K, Clancy SM, Lee V, Cienfuegos C, Wilmot C, Avis J, Hunyh T, et al. 2010. Deletion of the potassium channel $\mathrm{K}_{\mathrm{v}} 12.2$ causes hippocampal hyperexcitability and epilepsy. Nat Neurosci 13: 1056-1058.

Zuberi SM, Eunson LH, Spauschus A, De Silva R, Tolmie J, Wood NW, McWilliam RC, Stephenson JB, Kullmann DM, Hanna MG. 1999. A novel mutation in the human voltage-gated potassium channel gene $\left(K_{v} 1.1\right)$ associates with episodic ataxia type 1 and sometimes with partial epilepsy. Brain 122: 817-825. 


\section{$\&_{\mathrm{CSH}}^{\infty} \&$ Cold Spring Harbor

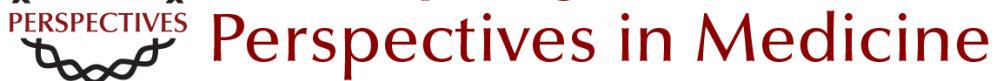

\section{Potassium Channels in Epilepsy}

Rüdiger Köhling and Jakob Wolfart

Cold Spring Harb Perspect Med 2016; doi: 10.1101/cshperspect.a022871

Subject Collection Epilepsy: The Biology of a Spectrum Disorder

The Epilepsy Spectrum: Targeting Future Research Challenges

Gregory L. Holmes and Jeffrey L. Noebels

Role of Sodium Channels in Epilepsy

David I. Kaplan, Lori L. Isom and Steven Petrou

\section{Mechanisms of Action of Antiseizure Drugs and the Ketogenic Diet Michael A. Rogawski, Wolfgang Löscher and Jong M. Rho}

Epilepsy and Autism

Ashura W. Buckley and Gregory L. Holmes

Immunity and Inflammation in Epilepsy Annamaria Vezzani, Bethan Lang and Eleonora Aronica

Hyperpolarization-Activated Cyclic Nucleotide-Gated (HCN) Channels in Epilepsy Gary P. Brennan, Tallie Z. Baram and Nicholas P. Poolos

The Role of Calcium Channels in Epilepsy Sanjeev Rajakulendran and Michael G. Hanna Interneuron Transplantation as a Treatment for Epilepsy

Robert F. Hunt and Scott C. Baraban
Common Mechanisms Underlying

Epileptogenesis and the Comorbidities of

Epilepsy

Andrey Mazarati and Raman Sankar

The Diathesis-Epilepsy Model: How Past Events Impact the Development of Epilepsy and Comorbidities

Christophe Bernard

Potassium Channels in Epilepsy

Rüdiger Köhling and Jakob Wolfart

\section{GABAergic Synchronization in Epilepsy} Roustem Khazipov

\section{Status Epilepticus}

Syndi Seinfeld, Howard P. Goodkin and Shlomo Shinnar

Neonatal and Infantile Epilepsy: Acquired and Genetic Models Aristea S. Galanopoulou and Solomon L. Moshé

Epigenetics and Epilepsy

David C. Henshall and Katja Kobow

Microcircuits in Epilepsy: Heterogeneity and Hub

Cells in Network Synchronization Anh Bui, Hannah K. Kim, Mattia Maroso, et al.

For additional articles in this collection, see http://perspectivesinmedicine.cshlp.org/cgi/collection/ 